\title{
Utilization of Microbial Consortia as Biofertilizers and Biopesticides for the Production of Feasible Agricultural Product
}

\author{
Renganathan Seenivasagan (D) and Olubukola Oluranti Babalola *(D) \\ Food Security and Safety Niche Area, Faculty of Natural and Agricultural Sciences, North-West University, \\ Mmabatho 2735, South Africa \\ * Correspondence: olubukola.babalola@nwu.ac.za; Tel.: +27-1-8389-2568; Fax: +27-1-8389-2134
}

Citation: Seenivasagan, R.; Babalola, O.O. Utilization of Microbial Consortia as Biofertilizers and Biopesticides for the Production of Feasible Agricultural Product. Biology 2021, 10, 1111. https:// doi.org/10.3390/biology10111111

Academic Editors: Ana Alexandre and Kathrin Wippel

Received: 8 September 2021

Accepted: 12 October 2021

Published: 28 October 2021

Publisher's Note: MDPI stays neutral with regard to jurisdictional claims in published maps and institutional affiliations.

Copyright: (c) 2021 by the authors. Licensee MDPI, Basel, Switzerland. This article is an open access article distributed under the terms and conditions of the Creative Commons Attribution (CC BY) license (https:// creativecommons.org/licenses/by/ $4.0 /)$.
Simple Summary: Recently in agriculture, the usage of chemical pesticides and fertilizers has increased tremendously. Additionally, it shows severe effects on human health, ecosystem, and groundwater. Environment-friendly methods are used to improve soil fertility, pests, and disease control. Biopesticide and biofertilizers have the future to upgrade sustainable agriculture for many years. This review highlights the efficacy of biofertilizers and biopesticides in improving crop yielding. It provides an eco-friendly and cost-effective method to get more yield for farmers. It describes the prominence of microbial inoculants in plant cultivation.

Abstract: Farmers are now facing a reduction in agricultural crop yield, due to the infertility of soils and poor farming. The application of chemical fertilizers distresses soil fertility and also human health. Inappropriate use of chemical fertilizer leads to the rapid decline in production levels in most parts of the world, and hence requires the necessary standards of good cultivation practice. Biofertilizers and biopesticides have been used in recent years by farmers worldwide to preserve natural soil conditions. Biofertilizer, a replacement for chemical fertilizer, is cost-effective and prevents environmental contamination to the atmosphere, and is a source of renewable energy. In contrast to chemical fertilizers, biofertilizers are cost-effective and a source of renewable energy that preserves long-term soil fertility. The use of biofertilizers is, therefore, inevitable to increase the earth's productivity. A low-input scheme is feasible to achieve farm sustainability through the use of biological and organic fertilizers. This study investigates the use of microbial inoculants as biofertilizers to increase crop production.

Keywords: bioinoculant; biopesticides; PGPR; microbial inoculants; organic farming; yield component

\section{Introduction}

Chemical fertilizers and pesticide dependence in conventional agriculture have increased, due to the significant growth of the human population and food demands [1]. Plant nutrition plays a major role in the increased demand for food supply. An increase in crop production has made it possible through the use of commercial artificial fertilizers. Phosphorus, nitrogen, and potassium fertilizer have frequently increased for crop production and agricultural systems with low cost [2]. Soil quality deterioration reversed biodiversity, and increased water and air pollution, and human health has also created excess use of chemical fertilizer [3]. The agriculture ecosystem, soil fertility, and cultivated crop growth get affected, due to excessive usage of chemical pesticides [4]. To overcome such drawbacks, a biofertilizer, a biological agent, is used for convalescing this problem. The loss of topsoil, soil infertility, plant growth reduction, reduced yield index, and gradual decrease of indigenous microbial diversity could be managed by microbial inoculants using agricultural practice. Pesticides and chemical fertilizers create environmental issues that 
microbial inoculants can comfortably overcome, which serves as a potential alternative and psychostimulants $[5,6]$.

For a healthy environment, the management of integrated nutrient systems and sustained agricultural productivity is greatly influenced by microbial inoculants [7]. Microbial inoculants or biofertilizers contain living microorganisms that colonize the rhizosphere and helps in the promotion of plant growth. The converts the insoluble elements in the soil to a soluble form by a biological process similar to rock phosphate solubilization and nitrogen fixation [8]. Beneficial microorganisms utilized in biofertilizers improve microflora, soil health, plant growth, plant disease control, and protect the plant from pests [9]. There are beneficial microbial inoculants, such as nitrogen fixer, phosphate, sulfur, zinc solubilizer (VAM), and plant growth-promoting rhizobacteria, in biofertilizers. Plant growth-promoting rhizobacteria are bacteria that live freely on rhizosphere soil and promote plant growth. They also acts as biopesticides, based upon the ability or behavior of the crops and biocontrol agents (Nitrogen fixer, PSB, and SSB) [10].

'Biopesticide' implies the use of beneficial microorganisms to control the insects. However, the major constraint is the availability of biopesticides relative to the total cropped area. Specific pesticides, derived from natural materials, act as biopesticides, such as plants, animals, bacteria, and certain minerals [11]. Biopesticides are classified into 3 major categories: biochemical, plant, and microbial pesticides. All over the world, there are $90 \%$ of all biopesticides utilized. The most commercially successful biopesticide in the market is Bacillus thuringiensis (Bt) [12]. Modern agriculture requires biopesticide and biofertilizers, due to the demand for safe and residue-free crop production [3]. Therefore, to cater to the need, it is necessary that government, and nongovernment organizations should promote entrepreneurs for biofertilizers and biopesticides production.

The objective of this review is the improvement of plant growth and yield through various microbes, such as bacterial, fungal, virus, and algae inoculants as biofertilizer (nitrogen fixers, phosphate solubilizer (PSB), sulfur solubilizer, PGPR, VAM, and Azolla), PGPR (phosphate solubilizer, $\mathrm{N}_{2}$ fixers, phytohormones, siderophores, and antibiotics) and biopesticides (microbial, plant incorporated protection, and biochemical).

\section{Biofertilizer}

Microbial inoculants or biofertilizers are preparation containing viable algae, fungi, and bacteria alone or consortium together to support the plant growth and increase crop yield [13]. Biofertilizers contain beneficial microbes that improve soil chemical and biological characteristics by fixing nitrogen, cellulolytic activity, or phosphate. When they are applied to seed, plant surfaces, root, or soil, they inhabit the rhizosphere, and through their biological activity, they enhance nutrient bioavailability, promote plant's growth, and increase the soil microflora. Thereby, they are preparations that readily improve the fertility of the soil $[14,15]$. Rhizobium has symbiotic associations with legume roots, such as rhizobacteria, that reside on the surface of the root or in the soil of the rhizosphere. Broad-spectrum biofertilizers include Blue-Green Algae (BGA), Rhizobium, and Azolla are crop-specific bio inoculants, such as Azospirillum, Azotobacter, phosphorus solubilizing bacteria (PSB), vesicular-arbuscular mycorrhiza (VAM), and Anabaena, as nitrogen-fixing cyanobacteria $[15,16]$. These bacteria are known as biofertilizers and plant growth-promoting rhizobacteria (PGPR). Competition mechanisms and antagonism activity are carried out by the enzymatic activity of PGPR for crop production, such as the inhibition of phytohormones and phytoparasites; it also helps plants in withstanding stress by heavy metal contaminations and pollutants $[17,18]$.

Biofertilizers are eco-friendly, cost-effective, and can be produced in bulk on the farm itself if necessary. The crop yield is increased by $10-40 \%$ and up to 50 percent of nitrogen is fixed. The continuous application of biofertilizer of the land for 3-4 years can retain fertility, due to the efficiency of parental inoculums, which could maintain the growth and multiplication of plants effectively. They improve soil texture, $\mathrm{pH}$, and other properties [19]. 
Biofertilizers are renewable sources of plant nutrients complementing chemical fertilizers at a low cost. In comparison to chemical fertilizers, biofertilizers are environmentally friendly; can be produced from natural sources, prevented from damage but also helps in building up healthy soil, and to some extent, plants are cleansed from chemical fertilizers that are precipitated [20]. Considering biofertilizer as a modern tool for agriculture, its use is vital as components of integrated nutrient management, reduction in the usage of hazardous chemicals, cost-effective, and source of renewable energy for plants in sustainable agriculture [21] (Figure 1 and Table 1).

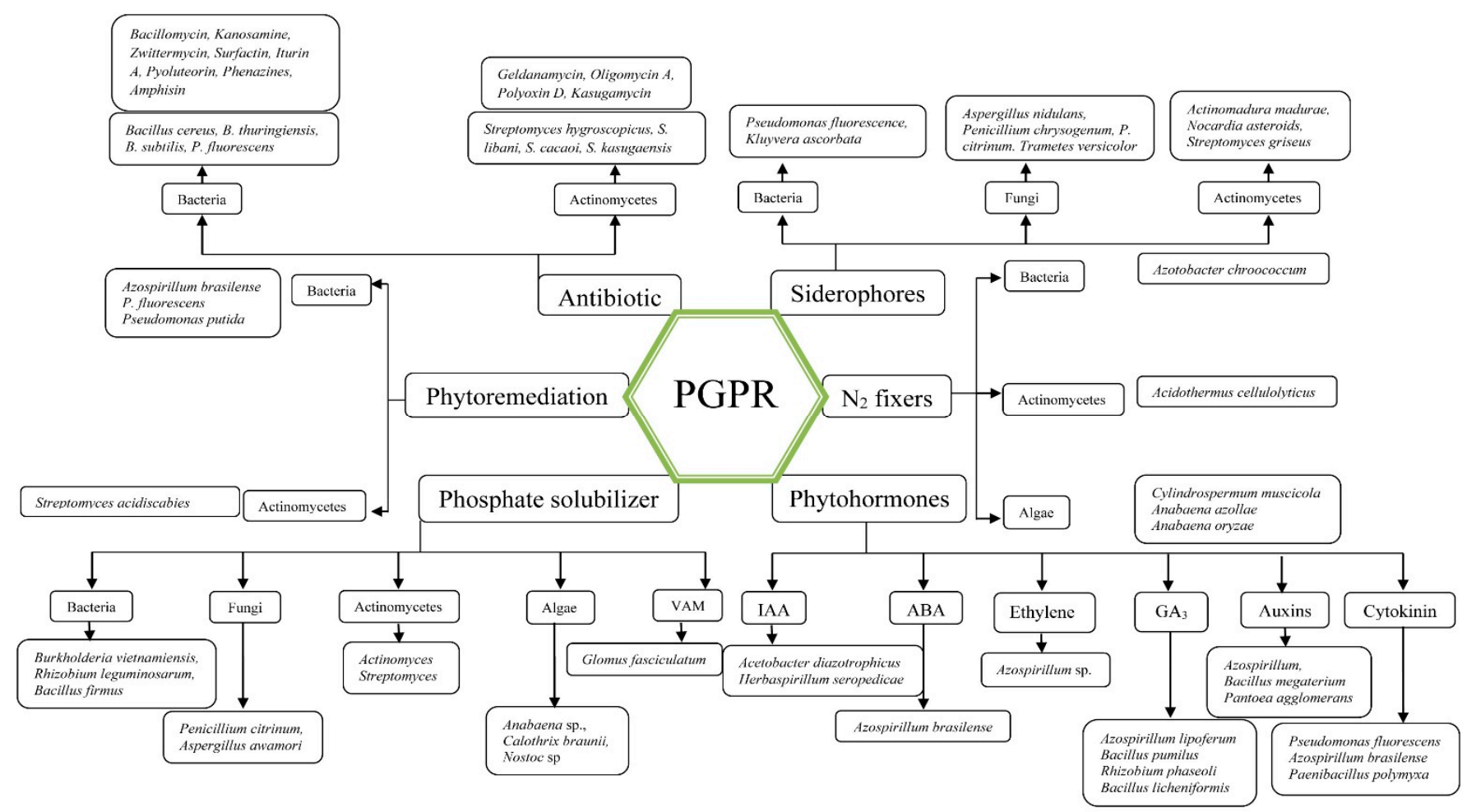

Figure 1. PGPR classification and involved microorganisms.

Table 1. Microbial inoculants used as biofertilizers, Plant Growth Promoting Rhizobacteria, and Biopesticides.

\begin{tabular}{lll}
\hline \multicolumn{1}{c}{ Biofertilizer } & \multicolumn{1}{c}{ PGPR } & \multicolumn{1}{c}{ Biopesticide } \\
\hline Rhizobium, Azotobacter, & Acetobacter, Aeromonas hydrophila, Azotobacter, & Bacillus thuringiensis, B. \\
Azospirillum brasilense, & Achromobacter, Alcaligenes, Anabaena, & thuringiensis var. kurstaki (Bt), B. \\
Azospirillum lipoferum, & Arthrobacter, Azoarcus, Azospirillum brasilense, & thuringiensis var. israelensis (Bt), B. \\
Azotobacter chroococcum, & A. irakense, A. lipoferum, Azotobacter, & thuringiensis var. tenebrionis, B. \\
Acetobacter diazotrophicus, & Acinetobacter calcoaceticus, A. baumannii, & thuringiensis var. aizawai, B. \\
Bacillus licheniformis, B. & Bacillus polymyxa, Beijerinckia, Burkholderia & thuringiensis japonensis, B. popilliae, \\
megaterium, B. mucilagenosus, & gladioli, Burkholderia cepacia, Clostridium, & B. lentimorbus, B. sphaericus, B. \\
B.edaphicus, B. subtilis, & Derxia, Enterobacter, Erwinia spp., Ewingella & pumilus, B. subtilis, B. firmus, \\
Actinomyces, Streptomyces, & americana, Escherichia vulneris, Flavobacterium, & Burkholderia cepacia, B. \\
Herbaspirillum seropedicae, & Frankia, Gluconacetobacter, Klebsiella, & amyloliquefaciens, B. licheniformis, \\
Rhizobium phaseoli, Thiobacillus & Mycobacterium phlei, Proteus penneri, & Erwinia amylovora, Pasteuria \\
thioxidans, Glomus fasciculatum, & Pseudomonas fluorescens, P. luteola, P. & penetrans, Pasteuria usage, \\
Blue Green Algae (BGA), & alcaligenes, P. putida, Rhizobium leguminosarum, & Pseudomonas spp., Streptomyces \\
and Azolla. & Rahnella aquatilis, Serratia plymuthica, S. ficaria, & griseoviridis, and Xanthomonas \\
& Sinorhizobium, Shigella spp., Vibrio fluvialis, & campestris pv. poannua, \\
& and Zoogloea & \\
\hline
\end{tabular}




\subsection{Nitrogen Fixers}

Nitrogen fixation is a dynamic and high-energy demanding process [26]. Elemental nitrogen conversion by biological nitrogen fixation is one way of converting into a plant's usable form. Organic compounds are transformed into inert atmospheric $\mathrm{N}_{2}$ by nitrogen-fixing bacteria [27]. In biofertilizers, nitrogen fixers or $\mathrm{N}_{2}$ fixing species are used as fertilizers containing living microbial inoculants or microorganism classes. Microbial inoculants, such as Azotobacter, Rhizobium, Blue-Green Algae (BGA), Azospirillum, and Azolla, are used as biofertilizers, which help in nitrogen fixation by converting atmospheric nitrogen to plant useable form. Legume plants have root nodules inhabiting bacteria belonging to the genera Sinorhizobium, Azorhizobium, Rhizobium, Bradyrhizobium, and Mesorhizobium, collectively called rhizobia [22]. When rhizobial culture is inoculated in the field, rhizobial symbiosis occurs, increasing the yield of pulse crops up to $15-20 \mathrm{~kg} \mathrm{~N} /$ ha by rhizobium, and crop yield is increased by up to $20 \%$ [28].

By nature, Azotobacter has a major role in the nitrogen cycle as it has a range of metabolic capabilities [29]. Along with nitrogen-fixing, Azotobacter also produces vitamins, such as riboflavin and thiamine [30], indole acetic acid (IAA), cytokinins (CK), and Gibberellins (GA), via plant hormones [31]. Atmospheric nitrogen is fixed and supplied as ammonium by Azotobacter chroococcum. Therefore changing over of ammonium ions improves plant development by root architecture advancing and seed germination enhancement [32]. Azotobacter is also used to kill pathogenic microorganisms surrounding crop plant root systems [33]. Azospirillum is another aerobic, free-living, motile, gram-negative bacterium that can thrive under flooding conditions [34], supporting various aspects of plant growth and development [35]. Infield trials and greenhouse experiments with Azospirillum species, such as Azospirillum, including A. irakense, A. lipoferum, A. halopraeferens, A. amazonense, and A. brasilense, shows improved crop yield and plant growth [34] (Table 2). Plants inoculated with Azospirillum showed higher water and mineral uptake leads to better yield [22]. Hungria et al. [36] reported that Azospirillum brasilense is competent enough to promote the growth of plants by fixation of nitrogen, which helps to save money.

For the global nitrogen cycle, cyanobacteria are very necessary for significant $\mathrm{N}_{2}$ fixers on earth [46]. Cyanobacteria, mostly used as nitrogen-fixing biofertilizers, includes Scytonema, Tolypothrix, Plectonema, Aulosira, Anabaena, and Nostoc [47,48]. Along with releasing growth-promoting substances, Cylindrospermum musicola also releases vitamins and nitrogen. In rice plants, it also improves root growth and yield [49]. Crop plants inoculated with Rhizobium sp. showed a substantial increase in growth and yield, through a high number of root nodules, compared to uninoculated plants [50].

\subsection{Phosphate Solubilizing Microorganisms}

Plant growth and metabolism processes are mainly affected by the nutrient nitrogen followed by phosphate [51]. In virtually all major metabolic processes, such as respiration, photosynthesis, energy accumulation, and transfer, signal transduction, cell enlargement, cell division, and macromolecular biosynthesis, they play an important role. Phosphate contributes to the resistance to disease and helps to survive winter rigors in plants $[52,53]$. As it is present in the form of insoluble phosphates, approximately 95-99 percent of soil phosphorous is unusable for plants [54]. The P-solubilizing potential of microbial inoculants (biofertilizers) is used as an environmentally safe alternative to further chemicalbased P fertilizer applications in agricultural soil [55]. Phosphorous can be solubilized by many microorganisms, including bacteria, fungi, actinomycetes, and even algae, such as Cyanobacteria and Mycorrhiza [1,56].

The most popular inoculants for phosphorus solubilizing bacteria (PSB) belong to the genera Pseudomonas spp. and Bacillus [57,58]. Other bacteria identified include Serratia, Rhodococcus, Chryseobacterium, Phyllobacterium, Arthrobacter, Delftia sp., Gordonia, [37], Xanthomonas [38], Azotobacter [39], Enterobacter, Pantoea, Klebsiella [40,41], Vibrio proteolyticus[42], Beijerinckia, Burkholderia, Erwinia, Flavobacterium, Microbacterium and Rhizobium [35], 
Xanthobacter agilis [43]. By releasing complexing or mineral dissolving compounds, such as (i) organic acid anions, protons, siderophores, $\mathrm{CO}_{2}$, and hydroxyl ions; (ii) extracellular enzyme release; and (iii) substrate degradation and P release, the soil microorganism employs P-solubilization mechanisms [59]. Organic acids are low molecular weight, such as citric and gluconic acids, which are synthesized by PSB during inorganic P solubilization [60]. The phosphate with the chelating cations of carboxyl and hydroxyl groups binds with organic acids, thereby releasing soluble phosphate and inducing soil acidification [61]. Heavy metal immobilization is performed by phosphate fertilizers. Microorganisms and plants solubilize insoluble phosphate compounds using their phosphatase enzyme and organic acids $[62,63]$.

Table 2. Microbial inoculants in phosphate, sulphate, zinc solubilizer and nitrate, siderophore producers are used as biofertilizer.

\begin{tabular}{|c|c|c|c|c|c|}
\hline Types & Bacteria & Fungi/VAM & Actinomycetes & Cyanobacteria/Yeast & References \\
\hline PSM * & $\begin{array}{l}\text { Alcaligenes sp., Aerobacter aerogenes, } \\
\text { Achromobacter sp., Actinomadura } \\
\text { oligospora, Agrobacterium sp., } \\
\text { Azospirillum brasilense, Bacillus } \\
\text { circulans, B.cereus, B.fusiformis, B. } \\
\text { pumilus, B. megaterium, B. mycoides, B. } \\
\text { polymyxa, B. coagulans, B.chitinolyticus, } \\
\text { B. subtilis, Bradyrhizobium sp., } \\
\text { Brevibacterium sp., Citrobacter sp., } \\
\text { Pseudomonas putida, P. striata, P. } \\
\text { fluorescens, P. calcis, P. corrugate, } \\
\text { Flavobacterium sp., Nitrosomonas sp., } \\
\text { Erwinia sp., Micrococcus sp., } \\
\text { Escherichia intermedia, Enterobacter } \\
\text { asburiae, Serratia phosphoticum, } \\
\text { Nitrobacter sp., Thiobacillus ferroxidans, } \\
\text { T. thioxidans, Rhizobium meliloti, and } \\
\text { Xanthomonas sp. }\end{array}$ & $\begin{array}{l}\text { Aspergillus awamori, A. niger, A. terreus, } \\
\text { A. flavus, A. nidulans, A. foetidus, A. } \\
\text { wentii, Fusarium oxysporum, Alternaria } \\
\text { teneius, Achrothcium sp., Penicillium } \\
\text { digitatum, P. lilacinium, P. balaji, P. } \\
\text { funicolosum, Cephalosporium sp., } \\
\text { Cladosprium sp., Curvularia lunata, } \\
\text { Cunnighamella, Candida sp., Chaetomium } \\
\text { globosum, Humicolainslens, H. lanuginosa, } \\
\text { Helminthosporium sp., } \\
\text { Paecilomycesfusisporous, Pythium sp., } \\
\text { Phoma sp., Populosporamytilina, } \\
\text { Myrotheciumroridum, Morteirella sp., } \\
\text { Micromonospora sp., Oideodendron sp., } \\
\text { Rhizoctonia solani, Rhizopus sp., Mucor } \\
\text { sp., Trichoderma viridae, Torula } \\
\text { thermophila, Schwanniomyces occidentalis, } \\
\text { and Sclerotium rolfsii. } \\
\text { Glomus fasciculatum (VAM) }\end{array}$ & $\begin{array}{l}\text { Actinomyces } \\
\text { sp. and } \\
\text { Streptomyces } \\
\text { sp. }\end{array}$ & $\begin{array}{l}\text { Anabaena sp., } \\
\text { Calothrix braunii, } \\
\text { Nostoc sp., and } \\
\text { Scytonema sp., }\end{array}$ & \\
\hline SSM * & $\begin{array}{l}\text { Acidothiobacillus, Thiomicrospira, } \\
\text { Thiosphaera, Paracoccus, Xanthobacter, } \\
\text { Alcaligenes, Pseudomonas, Thiobacillus } \\
\text { thiooxidans, T. ferrooxidans, T. thioparus, } \\
\text { T. denitrificans, and T. novellus }\end{array}$ & $\begin{array}{l}\text { Aureobasidium, Epicoccum, Penicillium, } \\
\text { Aspergillus, Alternariatenuis, } \\
\text { Aureobasidiumpullulans, } \\
\text { Epicoccumnigrum, } \\
\text { Scolecobasidiumconstrictum, and } \\
\text { Myrotheciumcinctum }\end{array}$ & & & {$[22,34,35,37-45]$} \\
\hline $\mathrm{NO}_{3} *$ & $\begin{array}{l}\text { Azospirillum lipoferum, A. brasilense, } \\
\text { Azoarcus, Azotobacter chroococcum, A. } \\
\text { peroxydans, A. nitrogenifigens, } \\
\text { Rhizobium, Bradyrhizobium, } \\
\text { Sinorhizobium, Azorhizobium, } \\
\text { Mesorhizobium, H. seropedicae, H. } \\
\text { rubrisubalbicans Burkholderia sp., } \\
\text { Rhizobium leguminosarum bv. trifolii, B. } \\
\text { vietnamiensis, } \\
\text { Gluconacetobacterkombuchae, G. } \\
\text { johannae, G. azotocaptans, G. } \\
\text { diazotrophicus, and Swaminathania } \\
\text { salitolerans }\end{array}$ & & $\begin{array}{l}\text { Acidothermus } \\
\text { cellulolyticus }\end{array}$ & $\begin{array}{l}\text { Cylindrospermum } \\
\text { musicola and } \\
\text { Anabaena azollae }\end{array}$ & \\
\hline Siderophore & $\begin{array}{l}\text { Bacillus sp., Ochrobactrum, Kluyvera } \\
\text { ascorbata, Salmonella, Enterobacter, } \\
\text { Yersinia, Mycobacterium, B. megaterium, } \\
\text { Ochrobactrum anthropi, Proteus vulgaris, } \\
\text { Pseudomonas fluorescence, P. putida, } \\
\text { Escherichia coli, Salmonella, Klebsiella } \\
\text { pneumoniae, Vibrio cholerae, V. } \\
\text { anguillarum, Aeromonas, Aerobacter } \\
\text { aerogenes, Yersinia, and Mycobacterium }\end{array}$ & $\begin{array}{l}\text { Aspergillus nidulans, A. versicolor, } \\
\text { Penicillium chrysogenum, P. citrinum, } \\
\text { Mucor, Rhizopus, Trametes versicolor, } \\
\text { Ustilago sphaerogina, Debaromyces sp., } \\
\text { and Rhodotorula minuta }\end{array}$ & $\begin{array}{l}\text { Nocardia } \\
\text { asteroids, } \\
\text { Streptomyces } \\
\text { griseus, and } \\
\text { Actinomadura } \\
\text { madurae }\end{array}$ & $\begin{array}{l}\text { Saccharomyces } \\
\text { cerevisiae (Yeast) }\end{array}$ & \\
\hline $\mathrm{ZSB} *$ & $\begin{array}{l}\text { Bacillus subtilis, Gluconacetobacter } \\
\text { diazotrophicus, Thiobacillus thioxidans, } \\
\text { and T. ferroxidans }\end{array}$ & Aspergillus niger and Penicillium luteum & & $\begin{array}{l}\text { Saccharomyces sp. } \\
\text { (Yeast) }\end{array}$ & \\
\hline
\end{tabular}

* PMS—Phosphate Solubilizing Microorganism, SSM—Sulphte Solubilizing Microorganism, ZSB—Zinc Solubilizing Microorganism.

Phosphate solubilizing and stress-tolerant bacteria Burkholderia vietnamiensis produces gluconic acids, and 2-ketogluconic, which is involved in solubilizing phosphate [62]. Tomar et al. [64] reported that black gram (Vigna mungo) and lentil (Lens esculentus) inoculated with $B$. firmus, a phosphate solubilizing bacteria showed significant results in the increase of seed yield. Chabot et al. [65] described that the inoculation of P-solubilizing Rhizobium leguminosarum leads to the growth of maize and lettuce. Some fungi, such as 
Penicillium and Aspergillus, act as phosphorus solubilizers [53]. Mittal et al. [66] isolated six P-solubilizing fungi, four strains of Penicillium citrinum, and two strains of A. awamori, from the rhizosphere of various crops. A. awamori showed shoot height increase of $7-12 \%$, seed number increase to three-fold, and increase in seed weight to two-fold, in comparison to uninoculated plants. Hajra et al. [67] reported that mycorrhizal plants had increased plant height and leaf area, in comparison to non-mycorrhizal plants, also showed a sharp decrease of nematode infection in plants (Table 2).

\subsection{Potassium Solubilizing Microorganisms}

Potassium is the third important plant growth nutrient that plays a vital role in plant metabolism, growth, and development. The plants would have poorly formed roots, grow slowly, produce small seeds and have lower yields without a sufficient supply of potassium [68] and increased vulnerability to diseases [69] and pests [70]. Potassium solubilizing microbes produce organic acids that can solubilize potassium rock [71]. Rhizosphere soil microbial inoculants, including Aspergillus, Bacillus sp., Clostridium, Burkholderia, Acidothiobacillus ferrooxidans, Pseudomonas, Paenibacillus sp., Bacillus mucilaginosus, B. circulans, and B. edaphicus has been reported to be released from potassium-bearing minerals in soils in an accessible form [72].

Organic acids are produced and secreted by microbial inoculants, such as Bacillus mucilagenosus and Bacillus edaphicus, in the solubilization of rock potassium [73]. Potassium solubilizing bacteria (KSB) beneficial effects have been reported on the growth of grape and cotton [74], sorghum [75], wheat [76], sudangrass [77], cucumber and pepper [66]. The significant mobilization of high potassium from waste mica, which acted as a potassium source for plant growth, resulted in wheat plants with Bacillus mucilaginosus, Azotobacter chroococcum, and Rhizobium [78].

\subsection{Sulfur Dissolving Microorganisms}

For the growth and development of plants, sulfur is one of the sixteen elements and the fourth main nutrient in crop production, after $\mathrm{N}, \mathrm{P}$, and $\mathrm{K}$. As a result of microbial activity, which includes mineralization, immobilization, oxidation, and reduction processes, sulfur transformations in the soil. Sulfur oxidizing bacteria synthesis of organic compounds from carbon dioxide by sulfur oxidation process and produce sulfuric acids. Enzyme sulfatase was used in the catalyzation of sulfur compound mineralization and transformation into forms accessible to plants [79]. After the inoculation of sulfur-oxidizing bacteria (Thiobacillus), seeds of high S-demanding crops have proved to be very effective, making sulfur more accessible to the plants. Some autotrophic species also exhibit chemolithotrophic growth on inorganic sulfur compounds, such as Acidothiobacillus, Thiosphaera, and Thiomicrospira, but some heterotrophs, such as Xanthobacter, Paracoccus, Pseudomonas, and Alcaligens [80]. Thiobacillus novellus is considered an optional chemoautotroph, while chemoautotrophs are obligatory for Thiobacillus ferrooxidans, $T$. thiooxidans, T. denitrificans and T. thioparus. Inorganic sulfur compounds are reduced or partially oxidized by a heterogeneous group of sulfur bacteria. Thiobacilli plays a significant function in the sulfur oxidation and oxidation process, producing acidity, which aids to solubilize plant nutrients and enhances soil fertility [81]. T. ferrooxidans and T. thioxidans inoculation increased sulfur oxidation to pyrite and subsequently, rock phosphate solubilization [82]. Elemental sulfur and thiosulphate are oxidized by some fungi, which include a range of Penicillium species, Epicoccum nigrum, Alternaria tenius, Scolecobasidium constrictum, Aspergillus, Aureobasidium pullulans, and Myrothecium cinctum [83] (Table 2).

\subsection{Zinc Solubilizers}

Microorganisms provide micronutrients, such as copper, iron, and zinc by transforming the nutrients present in the soil into accessible fertilizers. The solubilization of zinc by microorganisms, viz., T. thioxidans, Saccharomyces sp., and Bacillus subtilis. Bacillus sp. can be used as a biofertilizer for zinc, can replace zinc sulfate, which is costly, and can be used in 
conjunction with compounds, such as zinc sulfide ( $\mathrm{ZnS})$, zinc oxide $(\mathrm{ZnO})$, zinc carbonate $\left(\mathrm{ZnCO}_{3}\right)$, and with cheap zinc compounds. Zinc, an important micronutrient for growth and metabolism, is needed by plants and microorganisms. Zinc is the main compound in an enzyme system, acting as a metal activator and co-factor for many enzymes [84]. Gluconacetobacter diazotrophicus, Pseudomonas, Aspergillus niger, and Penicillium luteum producing organic acid, such as gluconic acids; it derivatives as 2- and 2,5-keto-derivatives are $\mathrm{Zn}$ compound solubilizers [85]. Thiobacillus ferroxidans, T. thioxidans, and facultative oxidizers of thermophilic iron have enormous ability to solubilize sulfide ore zinc [86]. Bullen and Kemila [87] report that a few fungal sp. were affected by zinc. Aspergillus niger has been found to withstand a high level of zinc capable of growing below $1000 \mathrm{mg} \mathrm{Zn}$ and is used for zinc quantification in soils containing low zinc (Table 2).

\section{Plant Growth Promoting Rhizobacteria (PGPR)}

Soil inoculants or microbial inoculants are farm applications that stimulate the growth of plants and are beneficial microbes. Similar bacteria engage in a symbiotic association with crop plants, promoting both partners [14]. By stimulating growth regulators, these inoculants enhance plant nutrition and promote growth. Effective inoculants that increase the availability to plants of macronutrients, such as nitrogen and phosphorus, are nitrogen fixers and phosphate solubilizers [88]. These bacteria are classified as biofertilizers and rhizobacteria that promote plant growth. PGPR can be defined as free-living bacteria of the rhizosphere that enhance plant growth and function as specialists in biocontrol, biopesticides, or biofertilizers [10,89]. PGPR inoculants alternate with chemical fertilizers and pesticides as biofertilizers and/or antagonists of phytopathogens either directly or indirectly [90,91]. In generating various plant growth regulators and by mobilizing nutrients in soils, plant growth is stimulated. The PGPR action mechanisms are not fully known but are assumed to include: (i) Nitrogen fixation [92]; (ii) Organic phosphate and inorganic phosphate or other nutrient solubilization [93]; phytohormones, such as auxins, cytokinins [94], and gibberellins [95]; (iv) development of siderophores [96] and (v) plant defense by controlling or inhibiting phytopathogens, improving soil structure, and bioremediating contaminated soils by sequestering toxic heavy metals and destroying xenobiotic compounds (such as pesticides) [97,98]. The PGPR inoculant strains include species of Azotobacter, Azospirillum, Agrobacterium, Acinetobacter, Alcaligenes, Arthrobacter, Acetobacter, Achromobacter, Aerobacter, Burkholderia, Beijerinckia, Bacillus, Clostridium, Delfitia, Erwinia, Enterobacter, Xanthomonas, Klebsiella, Flavobacterium, Micrococcus, Pantoea agglomerans, Paenibacillus macerans, Rhizobium, Pseudomonas, Rhodobacter, Serratia, and Rhodospirrilum [23] (Figure 2 and Table 1).

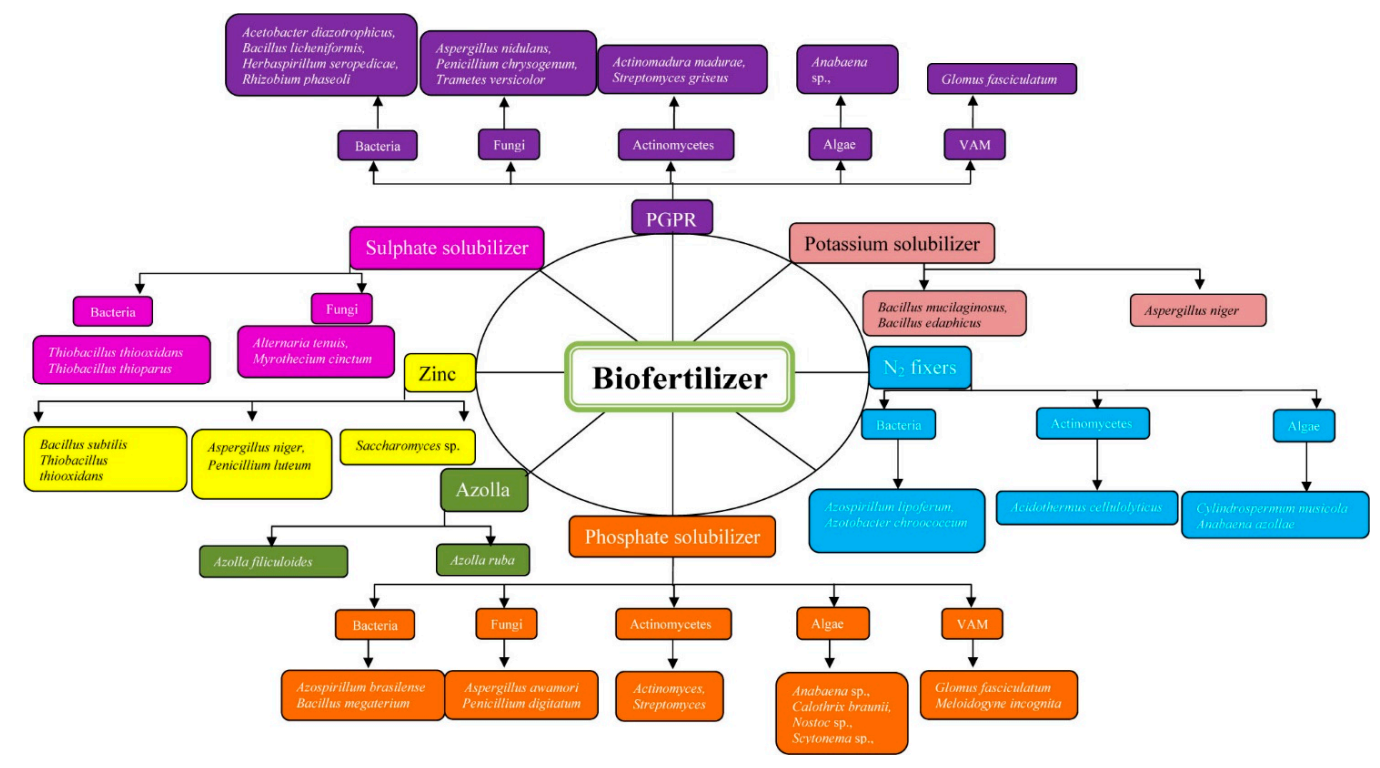

Figure 2. Biofertilizer classification and involved microorganisms. 


\subsection{Phytohormones}

Within the control of plant growth and production, phytohormones, such as ethylene, gibberellins, auxins, abscisic acid (ABA), and cytokinins, play a key role [98]. Gutierrez-Manero et al. [99] have been reported that certain rhizospheric bacteria, such as Bacillus licheniformis and Bacillus pumilus, are capable of producing gibberellins. Various PGPR inoculants, such as Azospirillum brasilense, Paenibacillus polymyxa, Arthrobacter giacomelloi, Bradyrhizobium japonicum, Bacillus licheniformi, and Pseudomonas fluorescens, have been reported for the production of cytokinin $[100,101]$. Tissue expansion is encouraged by cytokinin, including cell division and cell enlargement in the plant. The root to shoot ratio is found to be reduced [102]. Auxin is an important phytohormone and controls multiple developmental processes, including root cell division, root initiation, and cell enlargement [103]. Indole-3acetic acid (IAA) is produced by most rhizobacteria and stimulates plant growth promotion, especially root initiation and elongation [104]. IAA provided by PGPR is reported to increase root growth, modifying the plant (morphological functions) to uptake more nutrients from the soil (Table 3). Ethylene is another important phytohormone and plays a major role in the pathway of plant defense. Which inhibits root elongation and transport of auxins; abscission of different organs contributes to fruit maturation and promotes senescence [105]. Azospirillum brasilense produces ethylene, which probably facilitates the growth of root hair in tomato plants. Indeed A. brasilense inoculation had the mimicking effect of exogenous ethylene supply to plants, while this effect was inhibited by the addition of inhibitor for ethylene biosynthesis [106]. Lateral root extension and primary root elongation are promoted by gibberellins [107]. For the development of gibberellins, PGPR inoculants have been reported to produce gibberelline, several belonging to Acinetobacter calcoaceticus, Achromobacter xylosoxidans, Azotobacter sp., Azospirillum sp., Rhizobia, Gluconobacter diazotrophicus, Bacillus sp., and Herbaspirillum seropedicae [95]. Gutierrez-Manero et al. [99] documented that four different forms of GA are produced by Bacillus licheniformis and B. pumilus (Table 4).

Table 3. Plant growth promoting substance (acids) producing microorganisms.

\begin{tabular}{ll}
\hline \multicolumn{1}{c}{ Microorganisms } & \multicolumn{1}{c}{ Acids } \\
\hline $\begin{array}{l}\text { Bacillus pumils, B. subtilis, B. licheniformis, B. megaterium BHUPSB14, and } \\
\text { Paenibacillus polymyxa }\end{array}$ & $\begin{array}{l}\text { Gibberellins, Ethylene, Cytokinin, } \\
\text { and ACC deaminase }\end{array}$ \\
\hline $\begin{array}{l}\text { Pseudomonas tabaci, P. putida, P. syringae, P. fluorescens, P. fluorescens G20-18, } \\
\text { P. fluorescens BHUPSB06, P. aeruginosa, P. cepacia, and P. corrugata }\end{array}$ & $\begin{array}{l}\text { Ethylene, Indole-3-acetic acid, } \\
\text { Cytokinin, and ACC deaminase }\end{array}$ \\
\hline Rhizobium leguminosarum & $\begin{array}{l}\text { Indole-3-acetic acid, Cytokinin, and } \\
\text { HCN }\end{array}$ \\
\hline $\begin{array}{l}\text { Azospirillum brasilense and A. lipoferum, } \\
\text { Rhizobacterial isolates }\end{array}$ & $\begin{array}{l}\text { Indole-3-acetic acid, Zeatin, and } \\
\text { ethylene, Gibberellic acid (GA3), and } \\
\text { Abscisic acid (ABA) }\end{array}$ \\
\hline $\begin{array}{l}\text { Aeromonas veronii, Agrobacterium sp., Bradyrhizobium sp., Comamonas } \\
\text { acidovorans, Azotobacter chroococcum, Mesorhizobium ciceri, Azospirillum } \\
\text { amazonense, Rhizobium sp., Azotobacter sp., Kebsiellaoxytoca, Erwinia } \\
\text { herbicola, Bacillus subtilis, Serratia marcescens, and Enterobacter asburiae }\end{array}$ & Auxins \\
\hline Alcaligenes piechaudii and Enterobacter cloacae & Indole-3-acetic acid \\
\hline Variovorax paradoxus & Indole-3-acetic acid, ACC deaminase \\
\hline Pantoea agglomerans and Pantoea herbicola & ACC deaminase \\
\hline $\begin{array}{l}\text { Gluconobacter diazotrophicus } \\
\text { IAA and Auxin }\end{array}$ \\
\hline
\end{tabular}


Table 4. Plant growth promoting and bio controlling enzymes and acids producing phosphate solubilizing microbes.

\begin{tabular}{l} 
Microorganisms \\
\hline \\
Bacillus circulans, B.cereus, B. fusiformis, B.pumilus var.2, \\
B. megaterium, B. mycoides, B. polymyxa, B. coagulans B. \\
chitinolyticus, B. subtilis, B. subtilisvar.2, B. licheniformis, \\
B. amyloliquefaciens, B. atrophaeus, Paenibacillus \\
macerans, and B. japonicum
\end{tabular}

Enzymes

Acids

Lactic, malic, citric, itaconic, isovaleric, isobutyric, acetic, Phytase and gluconic, propionic, D-a-glycerophosphate heptonic, Caproic, Isocaproic, Formic, valeric, succinic, Oxalic, oxalacetic, malonic, and IAA

\begin{tabular}{ll}
\hline Bradyrhizobium sp., & Phytate \\
\hline $\begin{array}{l}\text { Burkholderia cepacia, Citrobacter sp., and Citrobacter } \\
\text { freundii }\end{array}$ & Acid phosphatase \\
\hline $\begin{array}{l}\text { Escherichia intermedia and E. freundii } \\
\end{array}$ & - \\
$\begin{array}{l}\text { Enterobacter asburiae, E. aerogenes, E. cloacae, E. } \\
\text { aerogenes, and E. intermedium }\end{array}$ & Acid phosphatase
\end{tabular}

IAA

Gluconic acid

Lactic
Lactic, itaconic, isovaleric,
isobutyric, acetic,
2-ketogluconic, gluconic,
succinic, acetic, glutamic,
oxaloacetic, pyruvic, malic,
fumaric, and
alpha-ketoglutaric

Pseudomonas putida, P. striata, P. fluorescens, P. calcis, P.
mendocina, and P. aeruginosa

Acid phosphatase,

Phytase, and

Phosphonoacetate

Lactic, malic, citric, gluconic,

2-ketogluconic acid, hydrolase and tartaric

\begin{tabular}{lll}
\hline Proteus mirabilis & Acid phosphatase & \\
\hline Serratia phosphoticum and S. marcescens & Acid phosphatase & Gluconic acid and IAA \\
\hline $\begin{array}{l}\text { Rhizobium meliloti, R. leguminosarum, R. leguminosarum } \\
\text { bv.phaseoli, R. leguminosarum bv. Trifolii, and } R \text {. } \\
\text { leguminosarum bv. Viciae }\end{array}$ & Phytate & $\begin{array}{l}\text { 2-ketogluconic acid, HCN, } \\
\text { and IAA }\end{array}$ \\
\hline Klebsiella aerogenes & C-P Lyase & \\
\hline $\begin{array}{l}\text { Sinorhizobium meliloti } \\
\text { Stenotrophomonas maltophilia }\end{array}$ & Phytate & $\begin{array}{l}\text { IAA, malic, succinic, and } \\
\text { fumaric }\end{array}$ \\
\hline Mesorhizobium cireri and M. mediterraneum & Gluconic acid \\
\hline Acetobacter sp. & Phytate & Gluconic acid \\
\hline
\end{tabular}

\subsection{Siderophore}

Siderophore is an essential element for various biological processes in all organisms in the biosphere. Bacteria, fungi, actinomycetes, and certain algae developing under low iron stress synthesize siderophores. It is an iron-binding protein that has a molecular weight range of 400-1500 Da [108]. According to the functional group, they are divided into four families, i.e., carboxylates, catecholate, hydroxamates, and pyoverdines. About 270 siderophores were characterized structurally out of the 500 types [109]. Microbial siderophores help to identify the complex of bacterial ferric siderophores and enhance plant iron uptake [110] and are also significant in the presence of metals, such as nickel and cadmium, in the uptake of iron by plants [111]. Ferric ion absorption through siderophore is largely used in the soil, human body, and marine environments by pathogenic and nonpathogenic microorganisms.

Organisms producing siderophore includes bacteria (Escherichia coli, Salmonella, Klebsiella pneumonia, Aerobacter aerogens, Mycobacterium sp., Yersinia, Enterobacter, Vibrio cholera, Aeromonas and Vibrio anguillarum); Fungi include (Trametes versicolor, Aspergillus versicolor, A. nidulans, Penicillium citrinum, P. chrysogenum, Ustilago sphaerogina, Rhizopus, Mucor, 
Rhodotorula minuta, Debaromyces sp., and Saccharomyces cerevisiae) [44], Actinomycetes constitute (Nocardia asteroids, Streptomyces griseus, and Actinomadura madurae), and Algae (Anabaena cylindrica and Anabaena flosaquae) [45] (Table 2). Siderophore produced by Azospirillum inoculation; it can modify the root morphology by releasing substances that control plant growth [34,112].

\subsection{Phytoremediation of Heavy Metals by PGPR}

Phytoremediation is an energy proficient and cheap method of detoxification. Plant metabolism is influenced by reducing the metal bioavailability by absorbing them in the biomass of shoot [17]. Heavy metal phytoremediation is performed using PGPR. Agricultural activities and industrialization are the major reasons for metal contamination. Metal contamination of soil has a significant bearing on PGPR capacities. Upkeeping of metal homeostasis opposition in bacteria is achieved via the synthesis of binding proteins, sequestration, detoxification, reduced uptake, and active efflux [113]. Singh et al. [114] revealed that heavy metal contamination of soil caused the blocking of functional molecules, essential components dislodging in biomolecules, alteration of structure, and function of enzymes/protein. Heavy metals additionally repress biochemical processes, such as respiration and photosynthesis, resulting in a reduction of growth. The proliferation of root hair and drastic expansion of the surface area of root resulted after the inoculation of maize with Azospirillum brasilense [115]. Intense heavy metal tolerant Pseudomonas putida, and P. fluorescens PGPR have been successfully assessed under states of contaminated soils and hyperosmolarity [116]. In addition to PGPR, a significant part of phytoremediation is performed by mycorrhizal fungi [117]. Streptomyces acidiscabies E13 strain applies positive growth developing effects in nickel contaminated soil of cowpea most likely by producing hydroxamate siderophores and binding of iron and nickel [112].

\subsection{Antibiotic}

Several bacterial antibiotics were used, such as aldehydes, hydrogen cyanide, alcohols, sulfides and ketones, diacetyl phloroglucinol, xanthobaccin, 2,4-diacetylphloroglucinol (DAPG), viscosinamide, mupirocin, pyocyanin, phenazine-1-carboxylic acid, phenazine1-carboxamide (PCN), phenazine-1-carboxylic acid (PCA), hydroxy phenazines, zwittermicin A, butyrolactones, pyrrolnitrin, pyoluteorin, phenazine-1-carboxylic acid, kanosamine, oligomycin A, 2,4-diacetyl phloroglucinol, oomycin A, pyrrolnitrin [35,118], Agrocin 84, Agrocin 434 [119], herbicolin, phenazine [120], pyoluteorin, oomycin, siderophores, pyrrolnitrin, and hydrolytic enzymes, such as laminarinase, chitinase, Q-1,3-glucanase, lipase, and protease, as well as small molecules, such as hydrogen cyanide (HCN).

Bacillus sp. produces by circulin, polymyxin, and colistin, the majority of active compounds gram-negative and gram-positive bacteria along with many fungi [121]. Siddiqui et al. [122] reported the effect of Rhizobium to have higher colonization and siderophores production. Pseudomonas sp., producing HCN and DAPG, are contributing to the biological control of tomato canker bacteria [123]. Expression of various antibiotics by Pseudomonas was reported; phenazine, pyoluteorin [118], lipopeptide antibiotics [124] 2, 4-diacetylphloroglucinol [123] and bacterial antibiotic manufacturers are genetically manipulated, which is a powerful method for deciding their role in the suppression of diseases. Arabidopsis thaliana infected with Pseudomonas syringae gets protection against surfactin, which is produced by Bacillus subtilis. In addition, it protected the pathogen and also necessary for root colonization [125].

\section{Biofertilizer Carrier}

The carrier is the significant group of inoculants, which help deliver the appropriate volume of PGPM in superior physiological state. Assorted materials are used as inoculants carriers for having improved biological effectiveness, endurance, and shielding bacteria from abiotic and biotic stresses. The comprising elements of the carrier materials can be organic, inorganic, or synthetic. An appropriate carrier is chosen, depending on properties 
such as availability, low cost, easy use, packageability, and mixability. Additionally, the gas exchange must be allowed by the carrier, especially oxygen, which must have a high water-holding capacity and increased content of organic matter [126]. The physical form of biofertilizer is characterized by the carrier used. The mixture of soil carrier materials is utilized as dry inoculants, such as coal clays, peat, inert materials (bentonite, perlite, kaolin, silicates, and vermiculite), organic materials (sawdust, wheat bran, soybean meal, and composts), or inorganic soil (volcanic pumice or diatomite earth and lapillus). A variety of liquid inoculants, such as organic oils, oil-in-water suspensions, broth cultures, and minerals, can be utilized as carriers. Suitable carrier material for both bacterial inoculants and the plants themselves must be non-toxic. Moreover, Stephens and Rask [127]; Ferreira and Castro [128] expressed the properties of the carrier as promptly, plentifully, and locally assessable at less cost, easily sterilizable and neutral with a readily adjustable $\mathrm{pH}$. The last choice of carrier incorporates properties, such as survival during storage, microbial multiplication, planting machinery, and sufficient cost, the general strategy of cultivation (Table 5).

Table 5. Microbial inoculants carrier types as biofertilizer.

\begin{tabular}{|c|c|c|}
\hline Materials & Category & Reference \\
\hline Preservative and Culture media ( liquid and powder) & Bacterial cultures (lyophilized) & \\
\hline Alginate and xanthan gum & Biopolymer & \\
\hline $\begin{array}{l}\text { Black ash, paddy husk, black ash plus husk mixture, husk powder } \\
\text { and pressmud, soybean and peanut oils, farmyard manure, plant } \\
\text { debris, wheat bran, composts, spent mushroom composts, sugar } \\
\text { industry waste, agricultural waste material, soybean meal, coconut } \\
\text { shell powder, and teak leaf powder }\end{array}$ & Waste materials (Plant) & $\begin{array}{l}\text { Bashan and } \\
\text { de-Bashan, [129] }\end{array}$ \\
\hline Lignite, pressmud, charcoal, inorganic soil, coal, clays and peat & Soils & \\
\hline $\begin{array}{l}\text { Carrageenan, polyacrylamide, calcium sulfate, polysaccharide-like } \\
\text { alginate, ground rock phosphate, vermiculite, and perlite }\end{array}$ & Inert materials & \\
\hline
\end{tabular}

Tilak [130] wrote about Farmyard manure (FYM) using blends, such as FYM + charcoal and soil, FYM + soil, and FYM + charcoal + soil, account for high viable counts of Azospirillum and survival up to 31 weeks. For the production of inoculants, carriers such as vermiculite clay, farmyard manure, coconut shell powder, teak leaf powder, and compost were used [131]. Locally accessible materials, such as coffee waste, soil, lignite, pressmud, and charcoal, were found to be superior to other carriers, which includes peat for Azospirillum, with the survival of 200 days and the decline rate in Azospirillum population was much lower in pressmud [132]. Singaravadivel and Anthoni Raj [133] reported that black ash plus husk mixture, pressmud, husk powder, black ash, and paddy husk were suitable and efficient carriers for Rhizobium and were also comparable with peat and lignite.

\section{Biopesticides}

Compared to conventional pesticides, biopesticides pose less risk to humans and the environment, gaining global attention as a new instrument for destroying or controlling pest species such as weeds, plant diseases, and insects [134,135]. Most biopesticides are advantageous for non-target biological safety and higher selectivity [136]. Biopesticides are types of pesticides that are produced from naturally occurring substances that control pests in an eco-friendly way via nontoxic mechanisms. Microorganism-derived biopesticides (Nucleopolyhedrosis virus and Bacillus thuringiensis, Trichoderma), plants (Azadirachta and Chrysanthemum), and animals (nematodes) contain their products (microbial products and phytochemicals) or by-products (semiochemicals) and live species (natural enemies) [137]. Biopesticides are categorized into three main categories: (i) pest-controlled microorganisms (microbial pesticides), (ii) naturally occurring pest-controlled substances (biochemical pesticides), and (iii) plant-controlled pesticides with added genetic material (PIPs). The 
use of biopesticides has increased by about 10\% each year globally [138]. Biopesticides are natural or organically inferred agents, applied similarly to chemical pesticides, but accomplish environment-friendly pest management. All pest management products, particularly microbial agents, are helpful in control but need to be correctly formulated and used [139] (Figure 3 and Tables 1 and 6).

Table 6. Microbial-based biopesticides.

\begin{tabular}{|c|c|c|c|c|c|c|}
\hline $\begin{array}{l}\text { Micro } \\
\text { Organisms }\end{array}$ & Pest Control & Weed Control & $\begin{array}{l}\text { Plant Disease } \\
\text { Control }\end{array}$ & $\begin{array}{l}\text { Nematicides } \\
\text { Control }\end{array}$ & Fungicides & Reference \\
\hline Bacteria & $\begin{array}{l}\text { Bacillus thuringiensis, } B \text {. } \\
\text { thuringiensis var. kurstaki, B. } \\
\text { thuringiensis var. israelensis, } B \text {. } \\
\text { thuringiensis var. tenebrionis, } B \text {. } \\
\text { thuringiensis var. aizawai, B. } \\
\text { thuringiensis japonensis, B. popilliae, } \\
\text { B. lentimorbus, B. sphaericus, } \\
\text { Erwinia amylovora, and B. pumilus }\end{array}$ & $\begin{array}{l}\text { Xanthomonas } \\
\text { campestris pv. } \\
\text { Poannua }\end{array}$ & $\begin{array}{l}\text { Bacillus pumilus, } \\
\text { B. subtilis, } \\
\text { Pseudomonas } \\
\text { spp., } \\
\text { Streptomyces } \\
\text { griseoviridis, } \\
\text { and } \\
\text { Burkholderia } \\
\text { cepacia }\end{array}$ & $\begin{array}{l}\text { Bacillus firmus, } \\
\text { Pasteuria } \\
\text { penetrans, and } \\
\text { Pasteuria usage }\end{array}$ & $\begin{array}{l}\text { Bacillus amyloliq- } \\
\text { uefaciens, } B \text {. } \\
\text { licheniformis, } B \text {. } \\
\text { pumilus, and } B \text {. } \\
\text { subtilis }\end{array}$ & \\
\hline Fungi & $\begin{array}{l}\text { Beauveria bassiana, Metarhizium } \\
\text { anisopliae, Entomophaga, Zoopthora, } \\
\text { Paecilomyces fumosoroseus, } \\
\text { Normuraea, Lecanicillium lecanii, L. } \\
\text { longisporum, Lagenidium giganteum, } \\
\text { and Verticillium lecanii }\end{array}$ & $\begin{array}{l}\text { Colletotrichum } \\
\text { gloeosporioides, } \\
\text { Chondrostereum } \\
\text { purpureum and } \\
\text { Cylindrobasid- } \\
\text { ium } \\
\text { laeve }\end{array}$ & $\begin{array}{l}\text { Ampelomyces } \\
\text { quisqualis, } \\
\text { Candida sp., } \\
\text { Clonostachys } \\
\text { roseaf. } \\
\text { catenulate, } \\
\text { Coniothyrium } \\
\text { minitans, } \\
\text { Pseudozyma } \\
\text { flocculosa, } \\
\text { Trichoderma } \\
\text { harzianum, T. } \\
\text { koningii, T. } \\
\text { viride, and } \\
\text { Chaetomium } \\
\text { cupreum }\end{array}$ & $\begin{array}{l}\text { Paecilomyces } \\
\text { lilacinus, } \\
\text { Myrothecium } \\
\text { verrucaria, } \\
\text { Verticillium } \\
\text { chlamydospo- } \\
\text { rium, and } \\
\text { Pochonia } \\
\text { chlamydosporia }\end{array}$ & & $\begin{array}{l}{[24,25,137,} \\
140-146] .\end{array}$ \\
\hline Protozoa & $\begin{array}{l}\text { Nosema locustae, Thelohania, and } \\
\text { Vairimorpha }\end{array}$ & & & & & \\
\hline Nematodes & $\begin{array}{l}\text { Steinernema feltiae, S. carpocapsae, S. } \\
\text { glaseri, S. riobravis, and } \\
\text { Heterorhabditis heliothidis }\end{array}$ & & & & & \\
\hline Virus & $\begin{array}{l}\text { Tussock moth NPV, Pine sawfly } \\
\text { NPV, Granulosis viruses, Codling } \\
\text { moth granulosis virus (GV), Gypsy } \\
\text { moth nuclear polyhedrosis (NPV), } \\
\text { Nuclear polyhedrosis viruses, } \\
\text { non-occluded baculoviruses, } \\
\text { Adoxophyes orana granulovirus } \\
\text { (GV)+ Homona magnanima GV, } \\
\text { Cydia pomonella granulovirus, } \\
\text { Nucleopolyhedrovirus Neodiprion } \\
\text { abietis, Heliothis zea NPV, } \\
\text { Anagrapha falcifera NPV, Spodoptera } \\
\text { exigua NPV, Mamestra configurata } \\
\text { NPV, Ectropis obliqua hypulina } \\
\text { NPV, Laphygma exigua NPV, } \\
\text { Prodenia litura NPV, Buzura } \\
\text { suppressaria NPV, Gynaephora } \\
\text { ruoergensis NPV, Mythimna } \\
\text { separata NPV, Periplaneta fuliginosa } \\
\text { densovirus virus, Pieris rapae GV, } \\
\text { Mythimna separata GV, and Plutella } \\
\text { xylostella GV }\end{array}$ & & & & & \\
\hline
\end{tabular}

\subsection{Microbial Pesticides}

Microbial pesticides are early developed and genetically modified. Organisms, such as algae, protozoans, fungi, viruses, or bacteria, are widely used. They develop pestspecific toxin, that causes disease, prevents the development of other microorganisms through antagonism or different nontoxic mechanism of action, compared to traditional chemical pesticides [147]. Normally, used microbial biopesticides are living microorganisms, pathogenic to the pest of interest, which include bioinsecticides (Bt), bioherbicides (Phytophthora), and bio fungicides (Pseudomonas, Trichoderma, and Bacillus) [148]. Mi- 
crobial biopesticides comprise of microorganisms such as protozoa, bacteria, fungi, viruses, and oomycetes, which are generally used to control weeds, pestiferous insects, and plant pathogens biologically. In the market, $74 \%$ are guaranteed by bacterial biopesticides, $10 \%$ by fungal biopesticides, $10 \%$ by viral biopesticides, $8 \%$ by predator biopesticides, and $3 \%$ by others for a wide range of crops [149]. By generating toxic metabolites or various other modes, microbial pesticides can suppress different target pests [147]. The species used as microbial insecticides are generally nonpathogenic and nontoxic to all living organisms and not so firmly confined closely to the targeted pests [150].

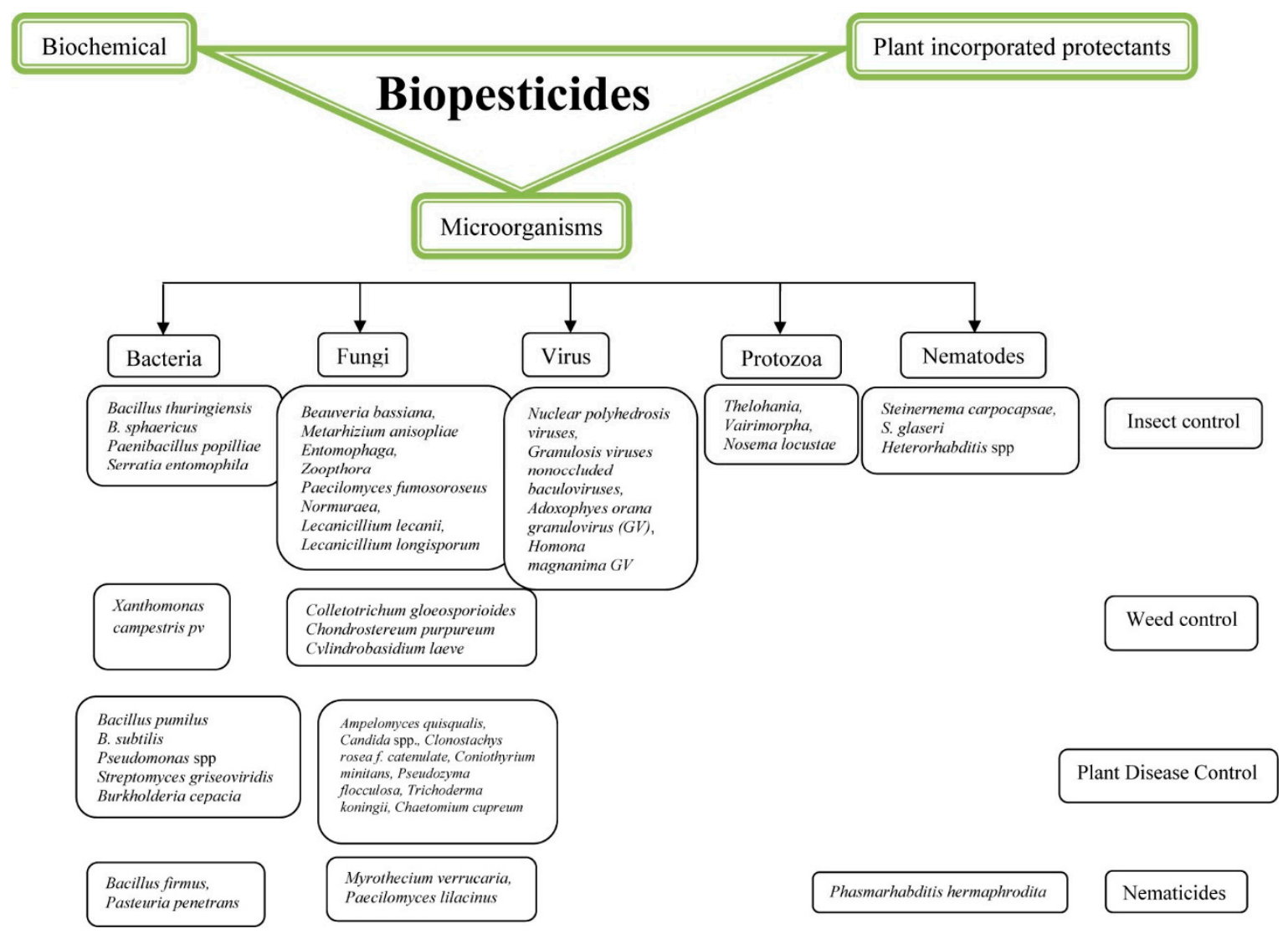

Figure 3. Biopesticides classification and involving microorganisms.

\subsubsection{Bacteria}

Bacterial biopesticides are used to monitor weeds, plant diseases, nematodes, and insects. Pest is controlled in various manners: delivering toxins, outcompeting and harming pathogens, promoting shoot and root growth, and producing anti-fungal compounds. Examples of bacterial biopesticides are Pseudomonas syringae, which controls bacterial spots, and Bacillus thuringiensis (Bt), which targets larvae. Bacillus thuringiensis (Berliner), the entomopathogenic bacterium, commonly recognized as a microbial biopesticide, which, during bacterial sporulation, generates crystal protein (d-endotoxin) when ingested by the susceptible insects triggers lysis of gut cells [140]. Spore formers, such as Pseudomonas aeroginosa, Serratia marcesens, Bacillus thuringiensis, and Bacillus popilliae, are used commercially for their efficacy and safety [141]. Pseudomonades, including P. fluorescence, P. syringae, and P. aeruginosa, are used to develop biopesticides. Some strains of Pseudomonas aureofaciens control plant pathogens, causing soft rots and damping-off [151]. Over half of mortality in Helicoverpa armigera and Spodoptera litura is by Pseudomonas sp., Bacillus subtilis, B. megaterium, and B. amyloliquefaciens [24]. Microbes like B. subtilis, B. pumilus, B. licheniformis, and B. amyloliquefaciens are marketed as biopesticides [142]. Bacillus sphaericus has been reported to have a dual role in larvicidal toxicity to Culex pipien, the blood-feeding mosquito, and the abil- 
ity to excrete extracellular alkaline protease (AP) in the medium used for growth [152]. Streptomyces griseoviridis is the first biofungicides available to combat root infecting fungi in greenhouse crops. Despite such products' long-term accomplishments, the global demand for new biopesticides remains [153,154]. Bacillus thuringiensis is sporulated, and it contains the proteins Cyt and Cry. Commercialized insecticides are products made up of $2 \% \mathrm{Bt}$, a combination of spores and protein crystals [155]. Bacillus thuringiensis can be more effective on Aedes aegypti, while the strain of B. sphaericus may be more effective on various mosquitoes, such as Culex quinquefasciatus [156]. In vegetables, it is recommended to use Bacillus thuringiensis (Bt) to manage insects, such as the velvet bean caterpillar, cabbage looper diamondback moth, and armyworm [143]. Sunitha et al. [157] found that the biopesticides based on B. thuringiensis are moderately active against Metarhizium anisopliae, while newer pesticides, such as spinosad and indoxacarb, were highly effective in controlling Maruca vitrata. Schunemann et al. [143] recommended various trade products of $B$. thuringiensis to control insect pests of agriculture, including mosquito species. Most formulations of spore-crystal toxins are obtained from a variety of strains, such as $B$. thuringiensis var. kurstaki, $B$. thuringiensis var. tenebrionis, $B$. thuringiensis var. israelensis, $B$. thuringiensis var. aizawai, and B. thuringiensis var. San Diego [143].

\subsubsection{Fungi}

In killing mites, weeds, nematodes, insects, or other fungi, new fungal biopesticides are used. Like bacteria, they produce toxins, such as bacteria, that outcompete targeted pathogens. These can also paralyze plant pathogens or insects by attacking them. Trichoderma harzianum, targeting Pythium, Rhizoctonia, and Fusarium, is also a fungicide [158]. Fungal species, such as Paecilomyces fumosoroseus, Beauveria bassiana, Verticillium lecani, Nomuraea rileyi, and Metarhizium anisopliae are used in insect control [25]. Beauverin peptide isolated from Beauveria bassiana is active against larvae of mosquito [159]. Fungal pathogens Metarhizium anisopliae and Beauveria bassiana have a lengthy- history in the perspective of agricultural pests. Current molecular techniques allow for the characterization and monitoring isolates of fungi, as well as for recognizing fungal isolates in the environment $[160,161]$. The codling moth and colorado potato beetle were regulated using Beauveria bassiana [162]. Biopesticides, such as $M$. anisopliae are commercially available, which controls several insect species [163]. Destruxins, a toxin produced by M. anisopliae, which has two separate virulence mechanisms, includes invading and destroying the insects, and third mechanisms by invading the ticks by a strategy of integument breakdown [164].

\subsubsection{Nematodes}

Several round colorless parasites, nematodes, and microscopic worms of the plant cause severe crop damage. Though targeting plants, some are essentially advantageous in attacking soil-dwelling insect pests, such as root weevils and cutworms [155]. Nematode biopesticides, such as Steinernema sp. and Heterorhabditis sp., that attack the hosts as contagious juveniles (IJs) are widely used [165]. Heterorhabditis megidis, H. bacteriophora, Steinernema scapterisci, S. carpocapsae, S. riobrave, S. glaseri, and S. feltiae are common entomogenous nematodes used as insecticides [144].

\subsubsection{Protozoa}

Protozoans are single-celled organisms surviving both in soil and water. Most species are parasites of insects, typically feeding on bacteria, while others feed on organic decay. More than any other insects, lepidopteran and orthopteran, hoppers especially are killed by Vairimorpha and Nosema comparing to other insects [166]. Nosema locustae spores enter and feed on the grasshopper body cavity. Mortality can take up to 3-4 weeks [167].

\subsubsection{Viruses}

Baculoviruses are a family of viral biopesticides believed to infect insects and arthropods related to them. Potential pesticides are the family Baculoviridae. This biopesticide is 
used in many parts of the world for the prevention of destructive caterpillar pests [168]. Nucleopolyhedro virus (NPVs) and Granulovirus (GVs) are found to be the two main genera of the Baculoviridae family [169]. These viruses are valuable, causing minimum damage, suitable for the crop, and management of pests, since only a few species of Lepidoptera larvae are infected, due to host specificity. The corn earworm Heliothis/Helicoverpa sp. by nuclear polyhedrosis virus and the codling moth of Cydia pomonella by granulosis virus are some examples. In contrast with traditional synthetic insecticides, Baculoviruses can control lepidopteran pests causing slight or no damage to the targeted species. The first viral biopesticide detected is the Heliothis nuclear polyhedrosis virus (NPV) [145]. Expression vectors, developed based on baculoviruses, were used in the production of viral pesticides using Autographa californica nucleopolyhedro virus (AcMNPV). Autographa gemmatalis control the soybean velvet bean caterpillar [146].

\subsection{Biochemical Pesticides}

Biochemical pesticides are equivalent to the naturally occurring or compounds, derived synthetically, that are used in pest control. The influence of growth and develop-ment of insect pests is achieved by the biochemical pesticides which are nontoxic in action destroying or attacking pest. Pheromones are substances that attract or repel pest or growth regulators of plant growth produced by biochemical pesticides that interfere in mating and growth of pests, including elements, such as insect sex pheromones interfering in mating, as well as attracting insect pests to traps using extracts of the scented plant. Chemical substances, such as pheromones, are emitted by living organisms that are used in sending messages to the same species individuals of mostly opposite sex [170]. Minimal crop damage can be achieved by using sex pheromones and plant protection measures by recognizing the crops and insects for further required action. The remarkably effective synthetic attractant is used in a low population, often use pheromone traps or a technique called "attracting and killing".

\subsection{Plant Incorporated Protectants (PIPS)}

Substances producing pesticides (PIPs) are introduced into the target crop plant genome, thereby providing the plant with capability of killing the pest. Scientists insert a insecticidal protein gene of Bacillus thuringiensis into the plant's genetic material thereby allow the plants to kill the pest. Environmental Protection Agency controls the protein, genetic material, and not the plant itself [170].

\section{Conclusions}

Biofertilizers based on microbial inoculants are attractive because they act in fixing nitrogen, phosphate, sulfate, potassium, zinc, and solubilize nutrients and enhance plant growth by hormonal action or antibiosis and decomposing organic residues. Plant reinforcers and phytostimulators can be used by plants to improve their growth when insufficient quantities of nitrogens are present. Moreover, they emerged from the soil and appeared to be competent in the rhizosphere. Plant growth-promoting rhizobacteria with numerous activities, such as nitrogen fixation, phytohormone production, micro- and macro-mineral solubilization, enzymes production, or fungicidal compounds of antibiotics synthesis. Siderophores, a competition with detrimental microorganisms, have bioremediation potentials by detoxifying contaminants, such as pesticides, heavy metals, and regulate phytopathogens, as biopesticides. They also improve and maintain the soil rhizosphere biologically by microbes, such as bacteria, fungi, algae, and actinomycetes. This review discusses the idea of single or consortiums have multiple activities, such as nitrogen-fixing, phosphate, sulfate, and zinc solubilization, through enzyme and acid production. The effect of microorganisms as biofertilizers and the role of biopesticides enhance plant growth by rendering them as tolerant to pests and to improve the crop health and food safety. 
Author Contributions: Conceptualization, R.S. and O.O.B.; writing-original draft preparation, R.S.; writing-review and editing, O.O.B.; visualization, O.O.B.; supervision, O.O.B.; funding acquisition, O.O.B. All authors have read and agreed to the published version of the manuscript.

Funding: This research received no external funding.

Institutional Review Board Statement: Not applicable.

Informed Consent Statement: Not applicable.

Acknowledgments: The authors like to thank the North-West University for a postdoctoral bursary.

Conflicts of Interest: The authors declare that they have no conflict of interest, either financial or commercial wise.

\section{References}

1. Santos, E.A.; Ferreira, L.R.; Costa, M.D.; Santos, J.B.; Silva, M.C.S.; Aspiazu, I. The effects of soil fumigation on the growth and mineral nutrition of weeds and crops. Acta Sci. Agron. 2012, 34, 207-212. [CrossRef]

2. Van Vuuren, D.P.; Bouwman, A.F.; Beusen, A.H.W. Phosphorus demand for the 1970-2100 period, A scenario analysis of resource depletion. Glob. Environ. Chang. 2010, 20, 428-439. [CrossRef]

3. Swapna, A.L. Development of biofertilizers and its future perspective. J. Pharm. 2013, 2, 327-332.

4. Rahman, K.M.A.; Zhang, D. Effects of fertilizer broadcasting on the excessive use of inorganic fertilizers and environmental sustainability. Sustainability 2018, 10, 759. [CrossRef]

5. Hou, M.P.; Babalola, O.O. Evaluation of plant growth-promoting potential of four rhizobacterial species for indigenous system. J. Cent. South Univ. 2013, 20, 164-171. [CrossRef]

6. Alori, E.T.; Dare, M.O.; Babalola, O.O. Microbial inoculants for soil quality and plant health. Sust. Agric. Rev. $2017,22,281-307$.

7. Sammauria, R.; Kumawat, S.; Kumawat, P.; Singh, J.; Jatwa, T.K. Microbial inoculants, potential tool for sustainability of agricultural production systems. Arch. Microb. 2020, 202, 677-693. [CrossRef] [PubMed]

8. Macik, M.; Gryta, A.; Frac, M. Biofertilizers in agriculture, An overview on concepts, strategies and effects on soil microorganisms. Adv. Agron. 2020, 162, 31-87. [CrossRef]

9. Deepak, B.; Mohammad, W.A.; Ranjan, K.S.; Narendra, T. Biofertilizers function as a key player in sustainable agriculture by improving soil fertility, plant tolerance, and crop productivity. Microb. Cell Fact. 2014, 13, 66.

10. Labuschagne, N.; Pretorius, T.; Idris, A.H. Plant growth-promoting Rhizobacteria as Biocontrol Agents against soil-borne Plant diseases. Microbiol. Monogr. 2010, 18, 211-230.

11. Sharma, K.R.; Raju, S.V.S.; Jaiswal, D.K.; Thakur, S. Biopesticides, an effective tool for insect pest management and current scenario in India. Ind. J. Agric. Allied Sci. 2018, 4, 59-62.

12. Valicente, F.H.; Tuelher, E.S.; Leite, M.I.S.; Freire, F.L.; Vieira, C.M. Production of Bacillus thuringiensis biopesticide using commercial Lab medium and agricultural by-products as nutrient sources. Braz. J. Maize Sorghum 2010, 9, 1-11. [CrossRef]

13. Yosefi, K.; Galavi, M.; Ramrodi, M.; Mousavi, S.R. Effect of bio-phosphate and chemical phosphorus fertilizer accompanied with micronutrient foliar application on growth, yield and yield components of maize (Single Cross 704). Aust. J. Crop Sci. 2011, 5, 175-180.

14. Babalola, O.O. Beneficial bacteria of agricultural importance. Biotechnol. Lett. 2010, 32, 1559-1570. [CrossRef] [PubMed]

15. Umesha, S.K.; Singh, P.P.; Singh, R. Microbial Biotechnology and Sustainable Agriculture. Biotechnol. Sustain. Agric. 2018, 185-205. [CrossRef]

16. Mohammadi, K.; Sohrabi, Y. Bacterial biofertilizers for sustainable crop production, A review. ARPN J. Agric. Biol. Sci. 2012, 7, 307-316.

17. Saharan, B.S.; Nehra, V. Plant growth-promoting rhizobacteria, a critical review. Life Sci. Med. Res. 2011, 21, 30.

18. Tak, H.I.; Ahmad, F.; Babalola, O.O. Advances in the application of plant growth-promoting rhizobacteria in phytoremediation of heavy metals. Rev. Environ. Contam. Toxicol. 2013, 223, 33-52. [PubMed]

19. Youssef, M.M.A.; Eissa, M.F.M. Biofertilizers and their role in management of plant parasitic nematodes, A review. J. Biotechnol. Pharm. Res. 2014, 5, 1-6.

20. Barman, M.; Paul, S.; Choudhury, A.G.; Roy, P.; Sen, J. Biofertilizers as prospective input for sustainable agriculture in India. Int. J. Curr. Microb. Appl. Sci. 2017, 6, 1177-1186. [CrossRef]

21. Ramasamy, M.; Geetha, T.; Yuvaraj, M. Role of Biofertilizers in Plant Growth and Soil Health. In Nitrogen Fixation; Everlon Cid Rigobelo and Ademar Pereira Serra; IntechOpen: London, UK, 2020. [CrossRef]

22. Gonzalez, L.J.; Rodelas, B.; Pozo, C.; Salmeron, V.; Martnez, M.V.; Salmeron, V. Liberation of amino acids by heterotrophic nitrogen-fixing bacteria. Amino Acids 2005, 28, 363-367. [CrossRef]

23. Glick, B.R. Plant growth-promoting bacteria, mechanisms and applications. Scientifica 2012, 2012, 963401. [CrossRef]

24. Gopalakrishnan, S.; Ranga Rao, G.V.; Humayun, P.; Rameshwar Rao, V.; Alekhya, G.; Simi, J.; Deepthi, K.; Sree Vidya, M.; Srinivas, V.; Mamtha, L.; et al. Efficacy of botanical extracts and entomopathogens on control of Helicoverpa armigera and Spodoptera litura. Afr. J. Biotechnol. 2011, 10, 16667-16673. 
25. Lacey, L.A.; Neven, L.G. The potential of the fungus, Muscodor albus, as a microbial control agent of potato tuber moth (Lepidoptera, Gelechiidae) in stored potatoes. J. Invert. Pathol. 2006, 91, 195-198. [CrossRef]

26. Rosenblueth, M.; Ormeno-Orrillo, E.; Lopez-Lopez, A.; Rogel, M.A.; Reyes-Hernández, B.J.; Martinez-Romero, J.C.; Reddy, P.M.; Martinez-Romero, E. Nitrogen Fixation in Cereals. Front. Microbiol. 2018, 9, 1794. [CrossRef] [PubMed]

27. Bakulin, M.K.; Grudtsyna, A.S.; Pletneva, A. Biological fixation of nitrogen and growth of bacteria of the genus Azotobacter in liquid media in the presence of Perfluorocarbons. Appl. Biochem. Microbiol. 2007, 4, 399-402. [CrossRef]

28. Dubey, R.C. A Textbook of Biotechnology, 4th ed.; S. Chand \& Co. Ltd.: New Delhi, India, 2006; p. 732. ISBN 81-219-2608-4.

29. Sahoo, R.K.; Ansari, M.W.; Dangar, T.K.; Mohanty, S.; Tuteja, N. Phenotypic and molecular characterization of efficient nitrogenfixing Azotobacter strains of the rice fields. Protoplasma 2013, 251, 511-523. [CrossRef]

30. Gauri, S.S.; Mandal, S.M.; Pati, B.R. Impact of Azotobacter exopolysaccharides on sustainable agriculture. Appl. Microbiol. Biotechnol. 2012, 95, 331-338. [CrossRef] [PubMed]

31. Abd El-Fattah, D.A.; Ewedab, W.E.; Zayed, M.S.; Hassaneina, M.K. Effect of carrier materials, sterilization method, and storage temperature on survival and biological activities of Azotobacter chroococcum inoculants. Ann. Agric. Sci. 2013, 58, 111-118. [CrossRef]

32. Gholami, A.; Shahsavani, S.; Nezarat, S. The Effect of Plant Growth Promoting Rhizobacteria (PGPR) on Germination seedling Growth and Yield of Maize. Int. J. Biol. Life Sci. 2009, 5, 1.

33. Mali, G.V.; Bodhankar, M.G. Antifungal and phytohormone production potential of Azotobacter chroococcum isolates from groundnut (Arachis hypogea L.) rhizosphere. Asian J. Exp. Sci. 2009, 23, $293-297$.

34. Sahoo, R.K.; Ansari, M.W.; Pradhan, M.; Dangar, T.K.; Mohanty, S.; Tuteja, N. Phenotypic and molecular characterization of efficient native Azospirillum strains from rice fields for crop improvement. Protoplasma 2014, 251, 943-953. [CrossRef] [PubMed]

35. Bhattacharyya, P.N.; Jha, D.K. Plant growth-promoting rhizobacteria (PGPR), emergence in agriculture. World J. Microbiol. Biotechnol. 2012, 28, 1327-1350. [CrossRef] [PubMed]

36. Hungria, M.; Campo, R.J.; Souza, E.M.; Pedrosa, F.O. Inoculation with selected strains of Azospirillum brasilense and A. lipoferum improves yields of maize and wheat in Brazil. Plant Soil 2010, 331, 413-425. [CrossRef]

37. Chen, Y.P.; Rekha, P.D.; Arun, A.B.; Shen, F.T.; Lai, W.A.; Young, C.C. Phosphate solubilizing bacteria from subtropical soil and their tricalcium phosphate solubilizing abilities. Appl. Soil Ecol. 2006, 34, 33-41. [CrossRef]

38. Sharan, A.; Darmwal, N.S.; Gaur, R. Xanthomonas campestris, a novel stress-tolerant, phosphate-solubilizing bacterial strain from saline-alkali soils. World J. Microbiol. Biotechnol. 2008, 24, 753-759. [CrossRef]

39. Farajzadeh, D.; Yakhchali, B.; Aliasgharzad, N.; Bashir, N.S.; Farajzadeh, M. Plant growth-promoting characterization of indigenous Azotobacteria isolated from soils in Iran. Curr. Microbiol. 2012, 64, 397-403. [CrossRef] [PubMed]

40. Selvakumar, G.; Kundu, S.; Joshi, P.; Nazim, S.; Gupta, A.D.; Mishra, P.K.; Gupta, H.S. Characterization of a cold-tolerant plant growth-promoting bacterium Pantoea dispersa 1A isolated from a sub-alpine soil in the North-Western Indian Himalayas. World J. Microbiol. Biotechnol. 2008, 24, 955-960. [CrossRef]

41. Shahid, M.; Hameed, S.; Imran, A.; Ali, S.; Elsas, J.D. Root colonization and growth promotion of sunflower (Helianthus annuus L.) by phosphate solubilizing Enterobacter sp. Fs-11. World J. Microbiol. Biotechnol. 2012, 28, 2749-2758. [CrossRef] [PubMed]

42. Vassilev, N.; Vassileva, M.; Bravo, V.; Fernandez-Serrano, M.; Nikolaeva, I. Simultaneous phytase production and rock phosphate solubilization by Aspergillus niger grown on dry olive wastes. Ind. Crops Prod. 2007, 26, 332-336. [CrossRef]

43. Vazquez, P.; Holguin, G.; Puente, M.; Lopez-cortes, A.; Bashan, Y. Phosphate solubilizing microorganisms associated with the rhizosphere of mangroves in a semi-arid coastal lagoon. Biol. Fertil. Soils 2000, 30, 460-468. [CrossRef]

44. Koulman, A.; Lee, T.V.; Fraser, K.; Johnson, L.; Arcus, V.; Lott, J.S.; Rasmussen, S.; Lane, G. Identification of extracellular siderophores and a related peptide from the endophytic fungus Epichloe festucae in culture and endophyte-infected Lolium perenne. Phytochemistry 2012, 75, 128-139. [CrossRef] [PubMed]

45. Harrington, J.M.; Parker, D.L.; Bargar, J.R.; Jarzecki, A.A.; Tebo, B.M.; Sposito, G.; Duckworth, O.W. Structural dependence of Mn complexation by siderophores, Donor group dependence on complex stability and reactivity. Geochim. Cosmochim. Acta 2012, 88, 106-119. [CrossRef]

46. Rodrigo, V.; Novelo, E. Seasonal changes in periphyton nitrogen fixation in a protected tropical wetland. Biol. Fertil. Soils 2007, 43, 367-372.

47. Abdel-Lateif, K.; Bogusz, D.; Hocher, V. The role of flavonoids in the establishment of plant roots endosymbioses with arbuscular mycorrhiza fungi, rhizobia, and Frankia bacteria. Plant Signal. Behav. 2012, 7, 636-641. [CrossRef] [PubMed]

48. Roy, M.; Srivastava, R.C. Assembling BNF system in rice plant, frontier areas of research. Curr. Sci. 2013, 104, 3-10.

49. Dey, H.S.; Tayung, K.; Bastia, A.K. Occurrence of nitrogen-fixing cyanobacteria in local rice fields of Orissa, India. Ecoprint 2010, 17, 77-85. [CrossRef]

50. Akhtar, M.S.; Siddiqui, Z.A. Use of plant growth-promoting rhizobacteria for the biocontrol of root-rot disease complex of chickpea. Australas. Plant Pathol. 2009, 38, 44-50. [CrossRef]

51. Widawati, S.; Suliasih, S. Augmentation of potential phosphate solubilizing bacteria (PSB) stimulates the growth of green mustard (Brasica caventis Oed.) in marginal soil. Biodiversitas 2006, 7, 10-14.

52. Khan, M.S.; Zaidi, A.; Ahemad, M.; Oves, M.; Wani, P.A. Plant growth promotion by phosphate solubilizing fungi-current perspective. Arch. Agron. Soil Sci. 2010, 56, 73-98. [CrossRef] 
53. Amit, S.; Priyanka, K.; Anju, N.; Ashwani, K. Isolation and Characterization of Phosphate Solublizing Bacteria from Anand Agriculture Soil. Int. J. Life Sci. Pharm. Res. 2012, 23, 256-266.

54. Kannapiran, E.; Ramkumar, V. Isolation of phosphate Solubilizing bacteria from sediments of Thondi coast, Palk Strait, Southeast coast of India. Ann. Biol. Res. 2011, 25, 157-163.

55. Alori, E.T.; Glick, B.R.; Babalola, O.O. Microbial phosphorus solubilization and its potential for use in sustainable agriculture. Front. Microbiol. 2017, 8, 971. [CrossRef] [PubMed]

56. Chun-qiao, X.; Ru-an, C.H.I.; Huan, H.E.; Wen-xue, Z.J. Characterization of tricalcium phosphate solubilization by Stenotrophomonas maltophilia YC isolated from pipe mines. J Cent. South Univ. Technol. 2009, 16, 581-587.

57. Babalola, O.O.; Glick, B.R. The use of microbial inoculants in African agriculture, current practice and prospects. J. Food Agric. Environ. 2012, 10, 540-549.

58. Alfa, M.I.; Adie, D.B.; Igboro, S.B.; Oranusi, U.S.; Dahunsi, S.O.; Akali, D.M. Assessment of biofertilizer quality and health implications of anaerobic effluent of cow dung and chicken droppings. Renew. Energy 2014, 63, 681-686. [CrossRef]

59. Sharma, S.B.; Sayyed, R.Z.; Trivedi, M.H.; Gobi, T.A. Phosphate solubilizing microbes, sustainable approach for managing phosphorus deficiency in agricultural soils. SpringerPlus 2013, 2, 587. [CrossRef]

60. Rodriguez, H.; Gonzalez, T.; Goire, I.; Bashan, Y. Gluconic acid production and phosphate solubilization by the plant growthpromoting bacterium Azospirillum spp. Naturwissenschaften 2004, 91, 552-555. [CrossRef] [PubMed]

61. Xu, R.K.; Zhu, Y.G.; Chittleborough, D. Phosphorus release from phosphate rock and an iron phosphate by low-molecular-weight organic acids. J. Environ. Sci. 2004, 16, 5-8.

62. Park, J.; Bolan, N.; Megharaj, M.; Naidu, R. Isolation of phosphate-solubilizing bacteria and characterization of their effects on lead immobilization. Pedologist 2010, 53, 67-75.

63. Igiehon, N.O.; Babalola, O.O. Biofertilizers and sustainable agriculture, exploring Arbuscular mycorrhizal fungi. Appl. Microbiol. Biotechnol. 2017, 101, 4871-4881. [CrossRef] [PubMed]

64. Tomar, S.S.; Pathan, M.A.; Gupta, K.P.; Khandkar, U.R. Effect of phosphate solubilizing bacteria at different levels of phosphate on black gram (Phaseolus mungo). Ind. J. Agron. 1993, 38, 131-133.

65. Chabot, R.; Antoun, H.; Cescas, M.P. Growth promotion of maize and lettuce by phosphate-solubilizing Rhizobium leguminosarum biovar. phaseoli. Plant Soil 1996, 184, 311-321. [CrossRef]

66. Mittal, V.; Singh, O.; Nayyar, H.; Kaur, J.; Tewari, R. Stimulatory effect of phosphate solubilizing fungal strains (Aspergillus awamori and Penicillium citrinum) on the yield of chickpea (Cicer arietinum L. cv. GPF2). Soil Biol. Biochem. 2008, 40, 718-727. [CrossRef]

67. Hajra, N.; Shahina, F.; Firoza, K. Biocontrol of root-knot nematode by Arbuscular mycorrhizal fungi in Luffa cylindrical. Pak. J. Nematol. 2013, 31, 77-84.

68. White, P.J.; Karley, A.J. Potassium. In Cell Biology of Metals and Nutrients, Plant Cell Monographs; Hell, R., Mendel, R.R., Eds.; Springer: Berlin/Heidelberg, Germany, 2010; Volume 17, pp. 199-224.

69. Vijay, S.M.; Maurya, B.R.; Jay, P.V. Does a rhizospheric microorganism enhance $\mathrm{K}^{+}$availability in agricultural soils. Microb. Res. 2014, 169, 337-347.

70. Troufflard, S.; Mullen, W.; Larson, T.R.; Graham, I.A.; Crozier, A.; Amtmann, A.; Armengaud, P. Potassium deficiency induced the biosynthesis of oxylipins and glucosinolates in Arabiodopsis thaliana. BMC Plant Biol. 2010, 10, 172. [CrossRef]

71. Han, H.S.; Lee, K.D. Effect of co-inoculation with phosphate and potassium solubilizing bacteria on mineral uptake and growth of pepper and cucumber. Plant Soil Environ. 2006, 52, 130-136. [CrossRef]

72. Liu, D.; Lian, B.; Dong, H. Isolation of Paenibacillus sp. and assessment of its potential for enhancing mineral weathering. Geomicrobiol. J. 2012, 29, 413-421. [CrossRef]

73. Sakr, W.R.; Elbagoury, H.M.; Sidky, M.A.; Ali, S.A. Production of organic roselle by natural minerals and biofertilizers. Am.-Eurasian J. Agric. Environ. Sci. 2014, 14, 985-995.

74. Sheng, X.F. Growth promotion and increased potassium uptake of cotton and rape by apotassium releasing strain of Bacillus edaphicus. Soil Biol. Biochem. 2005, 37, 1918-1922. [CrossRef]

75. Amrita, S.; Sunil, K.G. Microbial intervention in agriculture, An overview. Afr. J. Microbiol. Res. 2015, 9, 1215-1226. [CrossRef]

76. Sheng, X.F.; He, L.Y. Solubilization of potassium bearing minerals by a wild type strain of Bacillus edaphicus and its mutants and increased potassium uptake by wheat. Can. J. Microbiol. 2006, 52, 66-72. [CrossRef] [PubMed]

77. Basak, B.B.; Biswas, D.R. Co-inoculation of potassium solubilizing and nitrogen-fixing bacteria on solubilization of waste mica and their effect on growth promotion and nutrient acquisition by a forage crop. Biol. Fertil. Soils 2010, 46, 641-648. [CrossRef]

78. Singh, G.; Biswas, D.R.; Marwah, T.S. Mobilization of potassium from waste mica by plant growth-promoting rhizobacteria and its assimilation by maize (Zea mays) and wheat (Triticum aestivum L.). J. Plant Nutr. 2010, 33, 1236-1251. [CrossRef]

79. Hayes, J.E.; Richardson, A.E.; Simpson, R.J. Components of organic phosphorus in soil extracts that are hydrolysed by phytase and acid phosphatase. Biol. Fertil. Soils 2000, 32, 279-286. [CrossRef]

80. Stamford, N.P.; Santos, P.R.; Moura, A.M.; Santos, C.E.S.; Freitas, A.D.S. Biofertilizer with natural phosphate.; sulfur.; and Acidithio bacillus in a soil with low available-P. Sci. Agric. 2003, 60, 767-773. [CrossRef]

81. Yang, Z.H.; Stoven, K.; Haneklaus, S.; Singh, B.R.; Schnug, E. Elemental sulfur oxidation by Thiobacillus spp. and aerobic heterotrophic sulfur-oxidizing bacteria. Pedosphere 2010, 20, 71-77. [CrossRef]

82. Costa, A.C.A.; Medronhe, R.A.; Pecanha, R.P. Phosphate rock bioleaching. Biotechnol. Lett. 1992, 14, 233-238. [CrossRef] 
83. Shinde, D.B.; Patil, P.L.; Patil, B.R. Potential use of sulphur oxidizing microorganism as soil inoculant. Crop Res. 1996, 11, $291-295$.

84. Bapiri, A.; Asgharzadeh, A.; Mujallali, H.; Khavazi, K.; Pazira, E. Evaluation of zinc solubilization potential by different strains of Fluorescent Pseudomonads. J. Appl. Sci. Environ. Manag. 2012, 16, 295-298.

85. Saravanan, V.S.; Kalaiarasan, P.; Madhaiyan, M.; Thangaraju, M. Solubilization of insoluble zinc compounds by Gluconacetobacter diazotrophicus and the detrimental action of zinc ion $\left(\mathrm{Zn}^{2+}\right)$ and zinc chelates on root knot nematode Meloidogyne incognita. Lett. Appl. Microb. 2007, 44, 235-241. [CrossRef]

86. Bosecker, K. Bioleaching, metal solubilization by microorganisms. FEMS Microbiol. Rev. 1997, 20, 591-604. [CrossRef]

87. Bullen, P.; Kemila, A.P.F. Influence of $\mathrm{pH}$ on the toxic effect of zinc.; cadmium and pentachlorophenol on pure cultures of soil microorganisms. Environ. Toxicol. Chem. 1997, 16, 146-153.

88. Zayed, M.S. Improvement of growth and nutritional quality of Moringa oleifera using different biofertilizers. Ann. Agric. Sci. 2012, 57, 53-62. [CrossRef]

89. Enebe, M.C.; Babalola, O.O. The influence of plant growth-promoting rhizobacteria in plant tolerance to abiotic stress, a survival strategy. Appl. Microbiol. Biotechnol. 2018, 102, 7821-7835. [CrossRef]

90. Dutta, S.; Podile, A.R. Plant growth-promoting rhizobacteria (PGPR), Bugs to debug the root zone. Crit. Rev. Microbiol. 2010, 36, 232-244. [CrossRef] [PubMed]

91. Babalola, O.O. Does nature make provision for backups in the modification of bacterial community structures? Biotechnol. Genet. Eng. Rev. 2014, 30, 31-48. [CrossRef]

92. He, L.Y.; Zhang, Y.F.; Ma, H.Y.; Su, L.N.; Chen, Z.J.; Wang, Q.Y.; Meng, Q.; Fang, S.X. Characterization of copper resistant bacteria and assessment of bacterial communities in rhizosphere soils of copper-tolerant plants. Appl. Soil Ecol. 2010, 44, 49-55. [CrossRef]

93. Ahemad, M.; Khan, M.S. Evaluation of plant growth-promoting activities of rhizobacterium Pseudomonas putida under herbicide-stress. Ann. Microbiol. 2012, 62, 1531-1540. [CrossRef]

94. Frebort, I.; Kowalska, M.; Hluska, T.; Frebortova, J.; Galuszka, P. Evolution of cytokinin biosynthesis and degradation. J. Exp. Bot. 2011, 62, 2431-2452. [CrossRef] [PubMed]

95. Dodd, I.C.; Zinovkina, N.Y.; Safronova, V.I.; Belimov, A.A. Rhizobacterial mediation of plant hormone status. Ann. Appl. Biol. 2010, 157, 361-379. [CrossRef]

96. Ahmad, F.; Ahmad, I.; Khan, M.S. Screening of free-living rhizospheric bacteria for their multiple plant growth-promoting activities. Microb. Res. 2006, 36, 1-9. [CrossRef] [PubMed]

97. Ahemad, M. Implications of bacterial resistance against heavy metals in bioremediation, a review. IIOABJ 2012, 3, 39-46.

98. Rajkumar, M.; Ae, N.; Prasad, M.N.V.; Freitas, H. Potential of siderophore producing bacteria for improving heavy metal phytoextraction. Trends Biotechnol. 2010, 28, 142-149. [CrossRef] [PubMed]

99. Gutierrez-Manero, F.J.; Ramos-Solano, B.; Probanza, A.; Mehouachi, J.; Tadeo, F.R.; Talon, M. The plant growth-promoting rhizobacteria Bacillus pumilus and Bacillus licheniformis produce high amounts of physiologically active gibberellins. Physiol. Plant 2001, 111, 206-211. [CrossRef]

100. Perrig, D.; Boiero, M.L.; Masciarelli, O.A.; Penna, C.; Ruiz, O.A.; Cassan, F.D.; Luna, M.V. Plant growth-promoting compounds produced by two agronomically important strains of Azospirillum brasilense and implications for inoculant formulation. Appl. Microbiol. Biotechnol. 2007, 75, 1143-1150. [CrossRef]

101. Cassan, F.; Perrig, D.; Sgroy, V.; Masciarelli, O.; Penna, C.; Luna, V. Azospirillum brasilense Az39 and Bradyrhizobium japonicum E109, inoculated singly or in combination.; promote seed germination and early seedling growth in corn (Zea mays L.) and soybean (Glycine max L.). Eur. J. Soil Biol. 2009, 45, 28-35. [CrossRef]

102. Arkhipova, T.N.; Prinsen, E.; Veselov, S.U.; Martinenko, E.V.; Melentiev, A.I.; Kudoyarova, G.R. Cytokinin producing bacteria enhance plant growth in drying soil. Plant Soil 2007, 292, 305-315. [CrossRef]

103. Ding, Z.; Friml, J. Auxin regulates distal stem cell differentiation in Arabidopsis roots. Proc. Natl. Acad. Sci. USA 2010, 107, 12046-12051. [CrossRef]

104. Khare, E.; Arora, N.A. Effect of indole-3-acetic acid (IAA) produced by Pseudomonas aeruginosa in the suppression of charcoal rot disease of chickpea. Curr. Microbiol. 2010, 61, 64-68. [CrossRef] [PubMed]

105. Glick, B.R.; Cheng, Z.; Czarny, J.; Duan, J. Promotion of plant growth by ACC deaminase producing soil bacteria. Eur. J. Plant Pathol. 2007, 119, 329-339. [CrossRef]

106. Ribaudo, C.M.; Krumpholz, E.M.; Cassan, F.D.; Bottini, R.; Cantore, M.L.; Cura, J.A. Azospirillum sp. promotes root hair development in tomato plants through a mechanism that involves ethylene. J. Plant Growth Reg. 2006, 25, 175-185. [CrossRef]

107. Yaxley, J.R.; Ross, J.J.; Sherriff, L.J.; Reid, J.B. Gibberellin biosynthesis mutations and root development in pea. Plant Physiol. 2001, 125, 627-633. [CrossRef] [PubMed]

108. Arora, N.K.; Tewari, S.; Singh, R. Multifaceted Plant-Associated Microbes and Their Mechanisms Diminish the Concept of Direct and Indirect PGPRs. In Plant-Microbe Symbiosis, Fundamentals and Advances; Arora, N.K., Ed.; Springer: Berlin/Heidelberg, Germany, 2013; pp. 411-449.

109. Cornelis, P. Iron uptake and metabolism in pseudomonads. Appl. Microbiol. Biotechnol. 2010, 86, 1637-1645. [CrossRef] [PubMed]

110. Esuola, C.O.; Babalola, O.O.; Heine, T.; Schwabe, R.; Schlomann, M.; Tischler, D. Identification and characterization of a FADdependent putrescine N-hydroxylase (GorA) from Gordonia rubripertincta CWB2. J. Mol. Catal. B Enzym. 2016, 134, 378-389. [CrossRef] 
111. Dimkpa, C.; Svatos, A.; Merten, D.; Buchel, G.; Kothe, E. Hydroxamate siderophores produced by Streptomyces acidiscabies E13 bind nickel and promote growth in cowpea (Vigna unguiculata L.) under nickel stress. Can. J. Microbiol. 2008, 54, 163-172. [CrossRef] [PubMed]

112. Cruz, C.; Gouveia, C.; Dias, T.; Varma, A.; Babalola, O.O. How to disentangle changes in microbial function from changes in the microbial community. In Modern Tools and Techniques to Understand Microbes; Varma, A., Sharma, A.K., Eds.; Springer International Publishing AG: Basel, Switzerland, 2017; pp. 149-158.

113. Choudhary, R.; Shrivastava, S. Mechanism of zinc resistance in Pseudomonas putida strain S4. World J. Microbiol. Biotechnol. 2001, 17, 149-153. [CrossRef]

114. Singh, S.; Parihar, P.; Singh, R.; Singh, V.P.; Prasad, S.M. Heavy Metal Tolerance in Plants, Role of Transcriptomics, Proteomics, Metabolomics, and Ionomics. Front. Plant Sci. 2016, 6, 1143. [CrossRef] [PubMed]

115. Fallik, E.; Sarig, S.; Okon, Y. Morphology and physiology of plant roots associated with Azospirillum. In Azospirillum Plant Associations; Okon, Y., Ed.; CRC Press: Boca Raton, FL, USA, 1994; pp. 77-86.

116. Abdul, M.; Elisabeth, G.; Madalena, A. Management of microbial resources in the Environment: A Broad Perspective. In Management of Microbial Resources in the Environment; Springer: Dordrecht, The Netherlands, 2013; Volume 530.

117. Denton, B.P. Advances in phytoremediation of heavy metals using plant growth-promoting bacteria and fungi. MMG 445 Basic Biotechnol. 2007, 3, 1-5.

118. Loper, J.E.; Gross, H. Genomic analysis of antifungal metabolite production by Pseudomonas fluorescens Pf-5. Eur. J. Plant Pathol. 2007, 119, 265-278. [CrossRef]

119. Notz, R.; Maurhofer, M.; Schnider-Keel, U.; Duffy, B.; Haas, D.; Defago, G. Biotic factors affecting the expression of the 2, 4-diacetylphloroglucinol biosynthesis gene phlA in Pseudomonas fluorescens biocontrol strain CHA0 in the rhizosphere. Phytopathology 2001, 91, 873-881. [CrossRef]

120. Haas, D.; Defago, G. Biological control of soil-borne pathogens by fluorescent pseudomonads. Nat. Rev. Microbiol. 2005, 3, 307-319. [CrossRef]

121. Maksimov, I.V.; Abizgildina, R.R.; Pusenkova, L.I. Plant growth-promoting rhizobacteria as an alternative to chemical crop protectors from pathogens (Review). Appl. Biochem. Microbiol. 2011, 47, 333-345. [CrossRef]

122. Siddiqui, I.A.; Shaukat, S.S.; Sheikh, I.H.; Khan, A. Role of cyanide production by Pseudomonas fluorescens CHA0 in the suppression of root-knot nematode, Meloidogyne javanica in tomato. World J. Microbiol. Biotechnol. 2006, 22, 641-650. [CrossRef]

123. Lanteigne, C.; Gadkar, V.J.; Wallon, T.; Novinscak, A.; Filion, M. Production of DAPG and HCN by Pseudomonas sp. LBUM300 contributes to the biological control of bacterial canker of tomato. Phytopathology 2012, 102, 967-973. [CrossRef]

124. Koch, B.; Nielsen, T.H.; Sorensen, D.; Andersen, J.B.; Christophersen, C.; Molin, S.; Givskov, M.; Sorensen, J.; Nybroe, O. Lipopeptide production in Pseudomonas sp. strain DSS73 is regulated by components of sugar beet seed exudate via the Gac two-component regulatory system. Appl. Environ. Microbiol. 2002, 68, 4509-4516. [CrossRef]

125. Bais, H.P.; Fall, R.; Vivanco, J.M. Biocontrol of Bacillus subtilis against infection of Arabidopsis roots by Pseudomonas syringae is facilitated by biofilm formation and surfactin production. Plant Physiol. 2004, 134, 309-317.

126. Ben Rebah, F.B.; Tyagi, R.D.; Prevost, D. Wastewater sludge as a substrate for growth and carrier for rhizobia, the effect of storage conditions on survival of Sinorhizobium meliloti. Bioresour. Technol. 2002, 83, 145-151. [CrossRef]

127. Stephens, J.H.; Rask, H.M. Inoculant production and formulation. Field Crops Res. 2000, 65, 249-258. [CrossRef]

128. Ferreira, E.M.; Castro, I.V. Residues of the cork industry as carriers for the production of legumes inoculants. Silva Lusit. 2005, 13, 159-167.

129. Bashan, Y.; de-Bashan, L.E. Bacteria. In Encyclopedia of Soils in the Environment; Hillel, D., Ed.; Elsevier: Oxford, UK, 2005; pp. 103-115.

130. Tilak, K.V.B.R. Survival of Azospirillum brasilense in different carriers. Curr. Sci. 1979, 48, 412.

131. Tilak, K.V.B.R.; Subba Rao, N.S. Carries for legume inoculants. Fert. News 1978, 23, 25-28.

132. Sparrow, S.D.; Han, G.E. Survival of Rhizobium phaseoli in six carrier materials. Agron. J. 1981, 75, 181-184. [CrossRef]

133. Singaravadivel, K.; Anthoni Raj, S. Rice mill by products as carrier for Rhizobium. Legume Res. 1988, 11, $143-145$.

134. Saxena, S.; Pandey, A.K. Microbial metabolites as eco-friendly agrochemicals for the next millennium. Appl. Microbiol. Biotechnol. 2001, 55, 395-403. [CrossRef]

135. EPA. Ingredients Used in Pesticide Products: Pesticides. What Are Biopesticides? Available online: https://www.epa.gov/ ingredients-used-pesticide-products/what-are-biopesticides (accessed on 10 May 2021).

136. Cheng, X.L.; Liu, C.J.; Yao, J.W. The current status, development trend, and strategy of the bio-pesticide industry in China. Hubei Agric. Sci. 2010, 49, 2287-2290.

137. Leahy, J.; Mendelsohn, M.; Kough, J.; Jones, R.; Berckes, N. Biopesticide oversight and registration at the U.S. Environmental Protection Agency. In Biopesticides, State of the Art and Future Opportunities; Seiber, J.N., Coats, J., Duke, S.O., Gross, A.D., Eds.; ACS Symposium Series; American Chemical Society: Washington, DC, USA, 2014.

138. Bailey, K.L.; Mupondwa, E.K. Developing microbial weed control products, commercialization, biological and technological considerations. In Handbook of Sustainable Weed Management; Singh, H.P., Batish, D.R., Kohli, R.K., Eds.; The Haworth Press Inc.: Binghamton, NY, USA, 2006; pp. 431-473. 
139. Lacey, L.A.; Liu, T.X.; Buchman, J.L.; Munyaneza, J.E.; Goolsby, J.A.; Horton, D.R. Entomopathogenic fungi (Hypocreales) for control of potato psyllid, Bactericera cockerelli (Sulc) (Hemiptera, Triozidae) in an area endemic for zebra chip disease of potato. Biol. Control 2011, 56, 271-278. [CrossRef]

140. Jisha, V.N.; Smitha, R.B.; Benjamin, S.; Al, E.T. An overview on the crystal toxins from Bacillus thuringiensis. Adv. Microbiol. 2013, 3, 462-472. [CrossRef]

141. Roh, J.Y.; Choi, J.Y.; Li, M.S.; Jin, B.R.; Je, Y.H. Bacillus thuringiensis as a specific, safe, and effective tool for insect pest control. J. Microbiol. Biotechnol. 2007, 17, 547-549. [PubMed]

142. Fravel, D.R. Commercialization and implementation of biocontrol. Annu. Rev. Phytopathol. 2005, 43, 337-359. [CrossRef]

143. Schunemann, R.; Knaak, N.; Fiuza, L.D. Mode of action and specificity of Bacillus thuringiensis toxins in the control of caterpillars and stink bugs in soybean culture. ISRN Microbiol. 2014, 2014, 135675. [CrossRef] [PubMed]

144. Shapiro-Ilan, D.I.; Gouge, D.H.; Piggott, S.J.; Fife, P.J. Application technology and environmental considerations for use of entomopathogenic nematodes in biological control. Biol. Control 2006, 38, 124-133. [CrossRef]

145. Szewczyk, B.; Lobo de Souza, M.; Batista de Castro, M.L.; Moscardi, M.L.; Moscardi, F. Baculovirus biopesticides. In PesticidesFormulations, Effects, Fate; Stoytcheva, M., Ed.; IntechOpen Limited: London, UK, 2011. [CrossRef]

146. Moscardi, F.; Morales, L.; Santos, B. The successful use of AgMNPV for the control of velvetbean caterpillar, Anticarsia gemmatalis, in soybean in Brazil. In Proceedings of the VIII International Colloquium on Invertebrate Pathology and Microbial Control Embrapa Soja, Londrina, Brazil, 28 August 2002; pp. 86-91.

147. Bellinger, R.G. Organic Pesticides and Biopesticides, Clemson Extension, Home and Garden Information Center (HGIC). 2007. Available online: http:/ / www.clemson.edu/extension/hgic (accessed on 15 May 2012).

148. Quarles, W. New biopesticides for IPM and organic production. IPM Pract. 2011, 13, 7-8.

149. Thakore, Y. The biopesticide market for global agricultural use. Ind. Biotechnol. 2006, 2, 194-208. [CrossRef]

150. Chandler, D.; Bailey, A.S.; Tatchell, G.M.; Davidson, G.; Greaves, J.; Grant, W.P. The development, regulation and use of biopesticides for integrated pest management. Philos. Trans. R. Soc. Lond. B Biol. Sci. 2011, 366, 1987-1998. [CrossRef] [PubMed]

151. Berg, G. Plant-microbe interactions promoting plant growth and health, perspectives for controlled use of microorganisms in agriculture. Appl. Microbiol. Biotechnol. 2009, 14, 11-18. [CrossRef]

152. Afify, A.M.R.; Aboul-Soud, M.A.M.; Foda, M.S.; Sadik, M.W.A.; Kahil, T.; Asar, A.R.; Al-Khedhairy, A.A. Production of alkaline protease and larvicidal biopesticides by an Egyptian Bacillus sphaericus isolate. Afr. J. Biotechnol. 2009, 8, 3864-3873.

153. Glare, T.; Caradus, J.; Gelernter, W.; Jackson, T.; Keyhani, N.; Kohl, J.; Marrone, P.; Morin, L.; Stewart, A. Have biopesticides come of age? Trends Biotechnol. 2012, 30, 250-258. [CrossRef] [PubMed]

154. Anonymous. Biopesticides acquire mainstream status. Agrow World Crop. Prot. News 2013, 662, 1-5.

155. Bravo, A.; Likitvivatanavong, S.; Gill, S.; Soberon, M. Bacillus thuringiensis, a story of a successful bio-insecticide. Insect Biochem. Mol. Biol. 2011, 41, 423-431. [CrossRef] [PubMed]

156. Lacey, L.A.; Frutos, R.; Kaya, H.K.; Vail, P. Insect Pathogens as Biological Control Agents, Do They Have a Future? Biol. Control 2001, 21, 230-248. [CrossRef]

157. Sunitha, V.; Lakshmi, K.V.; Rao, G.V.R. Laboratory evaluation of certain insecticides against pigeonpea pod borer, Maruca vitrata. J. Food Legumes 2008, 21, 137-139.

158. Langewald, J.; Ouambama, Z.; Mamadou, A.; Peveling, R.; Stolz, I.; Bateman, R. Comparison of an organophosphate insecticide with a mycoinsecticide for the control of Oedaleus senegalensis Krauss (Orthoptera, Acrididae) and other Sahelian grasshoppers in the field at the operational scale. Biocontrol Sci. Technol. 1999, 9, 199-214. [CrossRef]

159. Uribe, D.; Khachatourians, G.G. Restriction fragment length polymorphism of mitochondrial genome of the entomopathogenic fungus Beauveria bassiana reveals high intraspecific variation. Mycol. Res. 2004, 108, 1070-1078. [CrossRef] [PubMed]

160. Hynes, M.J.; Murray, S.L.; Duncan, A.; Khew, G.S.; Davis, M.A. Regulatory genes controlling fatty acid catabolism and peroxisomal functions in the filamentous fungus Aspergillus nidulans. Eukaryot. Cell 2006, 5, 794-805. [CrossRef] [PubMed]

161. Takatsuka, J. Specific PCR assays for the detection of DNA from Beauveria bassiana F-263, a highly virulent strain affecting Japanese pine sawyer, Monochamus alternates (Coleoptera, Cerambycidae), by a sequence characterized amplified region (SCAR) marker. Appl. Entomol. Zool. 2007, 42, 619-628. [CrossRef]

162. Faria, M.R.; Wright, S.P. Mycoinsecticides and mycoacaricides, a comprehensive list with worldwide coverage and international classification of formulation types. Biol. Control 2007, 43, 237-256. [CrossRef]

163. Butt, T.M.; Jackson, C.W.; Magan, N. Fungi as Biocontrol Agents, Progress, Problems, and Potential; CABI: Swansea, UK, 2001; ISBN 9780851993560. [CrossRef]

164. Leemon, D.M.; Jonsson, N.N. Laboratory studies on Australian isolates of Metarhizium anisopliae as a biopesticide for the cattle tick Boophilus microplus. J Invertebr. Pathol. 2008, 97, 40-49. [CrossRef] [PubMed]

165. Koppenhofer, A.M.; Kaya, H.K. Entomopathogenic nematodes and insect pest management. In Microbial Biopesticides; Koul, O., Dhaliwal, G.S., Eds.; Taylor \& Francis: London, UK, 2002; pp. 277-305.

166. Lewis, L.C. Protozoan Control of Pests. In Encyclopedia of Pest Management; Pimental, D., Ed.; Taylor \& Francis: London, UK, 2002; pp. 673-676.

167. Cranshaw, W.; Hammon, R. Grasshopper control in gardens and small acreages. Colo. State Univ. Ext. Bull. 2013, 5, 536. Available online: http:/ / www.ext.colostate.edu/pubs/insect/05536.html/ (accessed on 15 October 2021). 
168. Szewczyk, B.; Rabalski, L.; Krol, E.; Sihler, W.; de Souza, M.L. Baculovirus biopesticides-a safe alternative to chemical protection of plants. J. Biopestic. 2009, 2, 209-216.

169. Van Regenmortel, M.H.V.; Fauquet, C.M.; Bishop, D.H.L.; Cartens, E.B.; Estes, M.K.; Lemon, S.M.; Maniloff, J.; Mayo, M.A.; McGeoch, D.J.; Pringle, C.R.; et al. Virus Taxonomy. Seventh Report of the International Committee on Taxonomy of Viruses; Academic Press: San Diego, CA, USA, 2000; p. 1162. ISBN 0123702003.

170. Mazid, S.; Kalita, J.C.; Rajkhowa, R.C. A review on the use of biopesticides in insect pest management. Int. J. Sci. Adv. Technol. 2011, 1, 169-178. 